\title{
Organic Aerosol Processing During Winter Severe Haze Episodes in Beijing
}

\section{Zhao, Jian}

2019-09-27

Zhao , J, Qiu, Y, Zhou, W , Xu , W , Wang , J , Zhang , Y, Li , L , Xie , C, Wang , Q, Du , W, Worsnop , D R , Canagaratna, M R, Zhou , L, Ge , X, Fu , P , Li , J , Wang , Z , Donahue, N M \& Sun , Y 2019 , ' Organic Aerosol Processing During Winter Severe Haze Episodes in Beijing ' , Journal of Geophysical Research : Atmospheres , vol. 124 , no. 17-18 , pp. 10248-10263 . https://doi.org/10.1029/2019JD030832

http://hdl.handle.net/10138/322239

https://doi.org/10.1029/2019JD030832

acceptedVersion

Downloaded from Helda, University of Helsinki institutional repository.

This is an electronic reprint of the original article.

This reprint may differ from the original in pagination and typographic detail.

Please cite the original version. 
Organic Aerosol Processing during Winter Severe Haze Episodes in Beijing Jian Zhao ${ }^{1,2}$, Yanmei Qiu ${ }^{1,2}$, Wei Zhou ${ }^{1,2}$, Weiqi Xu ${ }^{1,2}$, Junfeng Wang ${ }^{3,4}$, Yingjie Zhang ${ }^{1 \dagger}$, Linjie $\mathrm{Li}^{1,2}$, Conghui Xie ${ }^{1,2}$, Qingqing Wang ${ }^{1,2}$, Wei $\mathrm{Du}^{1 \sharp}$, Douglas R. Worsnop ${ }^{5}$, Manjula $\mathrm{R}$. Canagaratna ${ }^{5}$, Libo Zhou ${ }^{1}$, Xinlei Ge ${ }^{3}$, Pingqing $\mathrm{Fu}^{1,2}$, Jie Li ${ }^{1}$, Zifa Wang ${ }^{1,2}$, Neil M. Donahue $^{6,7}$, Yele Sun ${ }^{1,2,8^{*}}$

${ }^{1}$ State Key Laboratory of Atmospheric Boundary Layer Physics and Atmospheric Chemistry, Institute of Atmospheric Physics, Chinese Academy of Sciences, Beijing 100029, China

${ }^{2}$ University of Chinese Academy of Sciences, Beijing 100049, China

$9 \quad{ }^{3}$ Nanjing University of Information Science \& Technology, Nanjing 210044, China

$10 \quad{ }^{4}$ School of Engineering and Applied Sciences, Harvard University, Cambridge, Massachusetts 11 02138, United States

$12 \quad{ }^{5}$ Aerodyne Research Inc., Billerica, Massachusetts 01821, USA

$13{ }^{6}$ Department of Chemical Engineering, Carnegie Mellon University, Pittsburgh, PA, USA

$14{ }^{7}$ Center for Atmospheric Particle Studies, Carnegie Mellon University, Pittsburgh, Pennsylvania 15 15213, United States

$16{ }^{8}$ Center for Excellence in Regional Atmospheric Environment, Institute of Urban Environment,

17 Chinese Academy of Sciences, Xiamen 361021, China

18 'now at: State Key Joint Laboratory of Environmental Simulation and Pollution Control, College

19 of Environmental Sciences and Engineering, Peking University, Beijing 100871, China

${ }^{*}$ now at: Institute for Atmospheric and Earth System Research / Physics, Faculty of Science,

21 University of Helsinki, P.O. Box 64, 00014 Finland

$22 \quad$ *Correspondence: Yele Sun (sunyele@ mail.iap.ac.cn)

Key Points:

- Secondary organic aerosol $(46-66 \%)$ dominates organic aerosol during winter haze episodes in urban Beijing

- Aqueous phase-related OA fell well into a unique region in the triangle plot of $f_{44} \mathrm{vs} . f_{43}$

- Evidence showed potential formation of N- and S-containing organic compounds through aqueous-phase processing 


\section{Abstract}

Organic aerosol (OA) constituted a large fraction of aerosol particles during severe haze episodes in winter in northern China, yet our understanding of its physical and chemical processing was limited. Here we investigate the sources and processes of OA during four haze episodes in winter in 2016 using high resolution aerosol mass spectrometer. The $\mathrm{PM}_{2.5}$ reached $400 \mu \mathrm{g} \mathrm{m}^{-3} \mathrm{during}$ the severest episode (Ep1) when Beijing issued a red alert and implemented strict emission controls. Our results showed that secondary OA (SOA) dominated OA during haze episodes on average accounting $46-66 \%$, and was comparable to secondary inorganic aerosol (SIA) with the SOA/SIA ratios being $0.51-0.72$. Primary OA from fossil-fuel combustion, biomass burning and cooking presented very strong diurnal variations during haze episodes, and contributed up to $60 \%$ in OA at night. Comparatively, the changes in semi-volatile and lowvolatility SOA were relatively small except a substantial increase in aqueous phase related oxidized OA (aq-OOA) during Ep1 with high relative humidity $(\mathrm{RH})$ and aerosol water content. aq-OOA fell well into a small region in the middle of the triangle plot of $f_{44}$ vs. $f_{43}$ (fraction of $\mathrm{m} / \mathrm{z} 44$ and 43 in OA, respectively), which can be used as a diagnostic for the presence of aqueous-phase processing of SOA. In addition, the increases of $\mathrm{SO}_{2}{ }^{+} / \mathrm{SO}_{3}{ }^{+}$as a function of $\mathrm{RH}$, the triangle plot of $f_{\mathrm{H}_{2} \mathrm{SO}_{4}^{+}}$versus $f_{\mathrm{HSO}_{3}^{+}}$, and high nitrogen-to-carbon ratio in aq-OOA suggest the potential formation of sulfur- and nitrogen-containing organic compounds through aqueousphase processing.

\section{Introduction}

Haze pollution, characterized by high levels of fine particulate matter $\left(\mathrm{PM}_{2.5}\right)$ has become a major concern in megacities in China (Chan and Yao, 2008;Huang et al., 2014;Li et al., 2017) due to its detrimental effects on visibility (Zhang et al., 2010) and human health (Ebenstein et al., 2017). It also has a great influence on the direct and indirect radiative forcing over regional and hemispheric scales (Boucher et al., 2013). Recently, extensive studies have been conducted in the capital city of China - Beijing to investigate the $\mathrm{PM}_{2.5}$ formation pathways during haze episodes, particularly in winter with largely enhanced coal combustion emissions for residential heating (Elser et al., 2016; Hu et al., 2016;Liu et al., 2012; Quan et al., 2014;Sun et al., 2013a;Sun et al., 2014;Sun et al., 2016a;Sun et al., 2016b;Wang et al., 2015;Zhang et al., 2014;Zhang et al., 2015;Zhang et al., 2016;Zhang et al., 2018). For example, submicron aerosol $\left(\mathrm{PM}_{1}\right)$ increased by 
approximately 50-70\% in heating periods in Beijing due to coal combustion emissions (Wang et al., 2015;Zhang et al., 2016), and aerosol composition was dominated by organic aerosol (OA) (Sun et al., 2015). Therefore, understanding the chemical and physical processes of OA during haze episodes in heating season is of great importance for government to make mitigating strategies.

Previous studies showed that stagnant meteorological conditions, primary emissions, secondary formation, and regional transport are four major factors leading to the formation and evolution of severe haze episodes during wintertime in Beijing (Quan et al., 2014; Sun et al., 2014;Zheng et al., 2015b). Severe haze episodes are often associated with high relative humidity (RH), which facilitates aqueous-phase/heterogeneous secondary formation (Zheng et al., 2015b;Zhong et al., 2018) and leads to significantly enhanced sulfate concentrations (Sun et al., 2014;Zhang et al., 2014). Indeed, sulfate simulations were significantly improved during severely polluted haze events after including heterogeneous reaction mechanisms (Wang et al., 2014;Zheng et al., 2015a). A recent study also highlights the potential heterogeneous formation of hydroxymethane sulfonate (HMS) during Chinese winter haze episodes, which was previously misidentified as inorganic sulfate in aerosol mass spectrometer measurements. This partially explained the gap between modeled and measured sulfate mass concentrations (Song et al., 2019). Although the formation mechanisms of secondary inorganic aerosol (SIA) are relatively well understood, OA processing, especially during severe haze episodes, remains poorly characterized.

OA can be primary from direct emissions or secondary from oxidation of volatile organic compounds (VOCs). In Beijing, primary OA (POA) from coal combustion, cooking, traffic and biomass burning, and secondary OA (SOA) with different oxidation states have been ubiquitously observed (Hu et al., 2016;Huang et al., 2010;Sun et al., 2018). Xu et al. (2017b) found that more-oxidized, low-volatility oxygenated OA (LV-OOA) is associated with aqueousphase processing while less-oxidized, semi-volatile OOA (SV-OOA) is predominantly from photochemical production. Sun et al. (2018) showed that combustion-related primary emissions can be a considerable source of SV-OOA under low-temperature conditions. Recent studies also highlight the importance of aqueous phase-related OOA (aq-OOA) in OA (13-17\%) in Beijing (Sun et al., 2016b;Xu et al., 2019). While aq-OOA was found to increase the carbon oxidation states $(\overline{\mathrm{OS}} c)$ of SOA, the mass fraction of $m / z, 44$ in bulk OA $\left(f_{44}\right)$ was relatively stable across different RH levels (RH > 30\%), suggesting a different impact of primary and secondary OA on 
$\overline{\mathrm{OS}} c$ of OA (Sun et al., 2013a;Sun et al., 2016b). Despite this, our knowledge of OA processing under severe haze episodes is still limited, particularly for red alert periods (the daily $\mathrm{PM}_{2.5}$ concentration exceeded $300 \mathrm{\mu g} \mathrm{m}^{-3}$ for more than 3 days) with temporary emission controls. Therefore, a more detailed characterization of OA sources and processes is of great importance for elucidating its impact on haze formation.

In this study, an Aerodyne High-Resolution Time-of-Flight AMS (AMS hereafter) and a suite of collocated instruments were deployed to investigate aerosol sources and processing from 17 to 30 December of 2016 when a "red alert" was issued with a series of emission controls, including stopping construction activities, reducing the production of factories and the number of vehicles on the road, etc. The sources and variations of primary and secondary OA during severe haze episodes are elucidated, and the chemical processing of OA, particularly the formation of aqueous phase-related $\mathrm{OA}$ and organosulfur compounds are illustrated with Van Krevelen diagram, triangle plots, and fragmentation patterns. Also, the mass spectral patterns and oxidation states of water-soluble OA (WSOA) are characterized and compared with those of bulk OA.

\section{Experimental}

\subsection{Instrumentation and Measurements}

We measured non-refractory submicron aerosol species (NR-PM ammonium, and chloride) using an AMS at the tower branch of the Institute of Atmospheric Physics (IAP), Chinese Academy of Sciences, in Beijing from 17 to 30 December in 2016. This is a typical urban site affected by multiple local emissions, including nearby restaurants, traffic and a variety of residential sources (Sun et al., 2015). Detailed descriptions of the AMS are given in DeCarlo et al. (2006) and Canagaratna et al. (2007). The sampling setup, operation and calibration procedures of the AMS have been described elsewhere (Xu et al., 2015;Zhao et al., 2017).

Collocated measurements during this campaign included black carbon (BC) mass concentrations by a seven-wavelength Aethalometer AE33 (Magee Scientific Corp.), the light extinction coefficient of $\mathrm{PM}_{1}$ at $630 \mathrm{~nm}$ by a cavity-attenuated phase shift single scattering albedo monitor

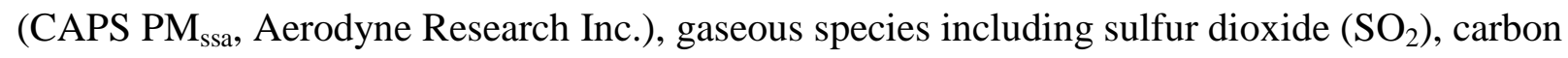


monoxide $(\mathrm{CO})$, and ozone $\left(\mathrm{O}_{3}\right)$ by gas analyzers (Thermo Scientific, model 43i, model 48i, and model 49i), respectively, and ammonia $\left(\mathrm{NH}_{3}\right)$ by a Los Gatos Research (LGR) analyzer. The $\mathrm{PM}_{2.5}$ mass concentrations were obtained from the measurements at the Olympic Center (http://zx.bjmemc.com.cn), which is $\sim 4 \mathrm{~km}$ from our sampling site. The meteorological parameters including wind speed (WS), wind direction (WD), temperature (T), and RH at 15 heights $(8,15,32,47,65,80,100,120,140,160,180,200,240,280$ and $320 \mathrm{~m})$ were obtained from the Beijing $325 \mathrm{~m}$ Meteorological Tower. In addition, wind profiles (200-5000 m) were measured with a Doppler Wind Lidar (Windcube 200, Leosphere, Orsay, France) with a time resolution of $10 \mathrm{~min}$ and a vertical resolution of $50 \mathrm{~m}$ (Figure 1), and the mixing layer height (MLH) was retrieved from the measurements of a single-lens ceilometer (CL51, Vaisala, Finland).

Daily $\mathrm{PM}_{2.5}$ quartz filters were also collected during this study period using a high-volume sampler (Tisch Environmental). The filter samples were first extracted with deionized water in brown bottles under ice bath, and then filtered with $0.45 \mu \mathrm{m}$ syringe filters. Under such conditions, aqueous oxidation of organics during the extraction was expected to be small. An aliquot of solution was aerosolized using pure Argon, dried with a silica-gel diffusion dryer, and then analyzed with the AMS. The detailed procedures for off-line analysis of filter samples can be found in Qiu et al. (2019).

\subsection{Data Analysis}

The raw mass spectra were analyzed using the standard AMS packages (PIKA 1.16I). The relative ionization efficiencies (RIE) of ammonium (4.8) and sulfate (1.4) were calibrated using pure ammonium nitrate and ammonium sulfate, respectively (Jayne et al., 2000), while the default RIE values were used for organics (1.4), nitrate (1.1) and chloride (1.3). A constant collection efficiency (CE) of 0.5 was used in this study considering the minor influences of 1) low relative humidity ( $<40 \%$, aerosol particles were dried by a silica gel diffusion dryer); 2 ) low fraction of ammonium nitrate fraction (<40\%, Figure S1); and 3) low particle acidity as indicated by the ratio of predicted $\mathrm{NH}_{4}{ }^{+}$to measured $\mathrm{NH}_{4}{ }^{+}(0.90$, Figure $\mathrm{S} 2 \mathrm{~b}$ ) (Matthew et al., 2008; Middlebrook et al., 2012). As shown in Figure S3, the total PM $_{1}$ mass tracked well with $\mathrm{PM}_{2.5}\left(r^{2}=0.93\right.$, slope $\left.=0.78\right)$ and $\mathrm{PM}_{1}$ light extinction $\left(r^{2}=0.98\right)$, further supporting that $\mathrm{CE}$ used in this study is reasonable. 
High-resolution mass spectra of organic matrix for $m / z$ 12-150 were analyzed by positive matrix factorization (PMF) with PMF2.exe algorithm (Paatero and Tapper, 1994), following the dataprocessing and factors-selecting steps given by Ulbrich et al. (2009) and Zhang et al. (2011). The major $m / z$ 's related to polycyclic aromatic hydrocarbons (PAHs), i.e., 152, 165, 178, 189, and 202 were also included (Dzepina et al., 2007). Detailed preparation of organic and error matrices were the same as those descripted in Xu et al. (2019). In total, six OA factors $\left(f_{\text {peak }}=0\right)$ were identified including three POA factors, i.e., fossil-fuel-related OA (FFOA) from coal combustion and traffic emissions, biomass burning OA (BBOA), and cooking-related OA (COA), and three SOA factors, i.e., SV-OOA, aq-OOA, and LV-OOA. We present detailed diagnostic plots of the PMF results in supplementary materials (Figures S4-S7). The mass spectra of OA factors were compared with those previously resolved at the same site (Xu et al., 2015;Zhao et al., 2017;Sun et al., 2016b; Xu et al., 2017b) and the standard mass spectral profiles given in $\mathrm{Ng}$ et al. (2011a) using the cosine similarity (i.e., uncentered correlation coefficient) (Ulbrich et al., 2009) and the modified correlation coefficients weighted by estimated signal to noise ratios (Costa, 2011). The results are consistent with the well-known Pearson product-moment correlation coefficient $r$ (or $r^{2}$ ) (Table S1). It should be noted that the aq-OOA spectrum showed high $m / z 29$ (mainly $\mathrm{CHO}^{+}$) than other OA factors. Considering that the error of $\mathrm{CHO}^{+}$could be underestimated due to the influence of adjacent ${ }^{15} \mathrm{NN}^{+}$, we also performed PMF analysis by increasing the error of $\mathrm{CHO}^{+}$ by a factor of 3 , and found that the changes in spectral profiles of OA factors including aq-OOA were negligible.

Elemental ratios including hydrogen-to-carbon $(\mathrm{H} / \mathrm{C})$, oxygen-to-carbon $(\mathrm{O} / \mathrm{C})$ and organic mass-to-organic carbon (OM/OC) ratios of both online and offline AMS measurements were calculated using the "Improved-Ambient (I-A)" method (Canagaratna et al., 2015), while nitrogen-to-carbon (N/C) was calculated using the "Aiken-Ambient (A-A)" method (Aiken et al., 2007; Aiken et al., 2008). On average, H/C, O/C and OM/OC ratios calculated by I-A method were $9 \%, 28 \%$ and $9 \%$, respectively, higher than those from the A-A method (Figure S8). It should be noted that the elemental ratios of WSOA were calculated with the fitted $\mathrm{CO}^{+}$which was approximately equal to $0.65 \times \mathrm{CO}_{2}{ }^{+}$, while the default fragmentation pattern, i.e., $\mathrm{CO}^{+}=$ $\mathrm{CO}_{2}{ }^{+}$was used for OA from online measurements. The O/C of WSOA would be $6 \%$ higher than the values in this study if assuming $\mathrm{CO}^{+}=\mathrm{CO}_{2}{ }^{+}$for elemental analysis (Figure $\mathrm{S} 8 \mathrm{~b}$ ). 
Aerosol water content (AWC) was predicted by ISORROPIA-II model (Fountoukis and Nenes, 2007; Nenes et al., 1998) using the measurements of inorganic species (nitrate, sulfate, ammonium and chloride), gaseous ammonia and meteorological parameters $(T, \mathrm{RH})$. Consistent with previous studies, AWC increased exponentially as a function of RH indicating that the increases in $\mathrm{RH}$ were associated with the corresponding increases in AWC although the decrease in temperature also played a role (Sun et al., 2013a;Wang et al., 2016). In addition, 48-hour back trajectories arriving at the observation site at a height of $200 \mathrm{~m}$ were calculated every two hours using HYSPLIT model (Draxler and Hess, 1998; Stein et al., 2015). The trajectories were classified into four air mass clusters that represent different potential source regions (Figure S9 and Table S2).

\section{Results and Discussion}

191

\subsection{General Descriptions}

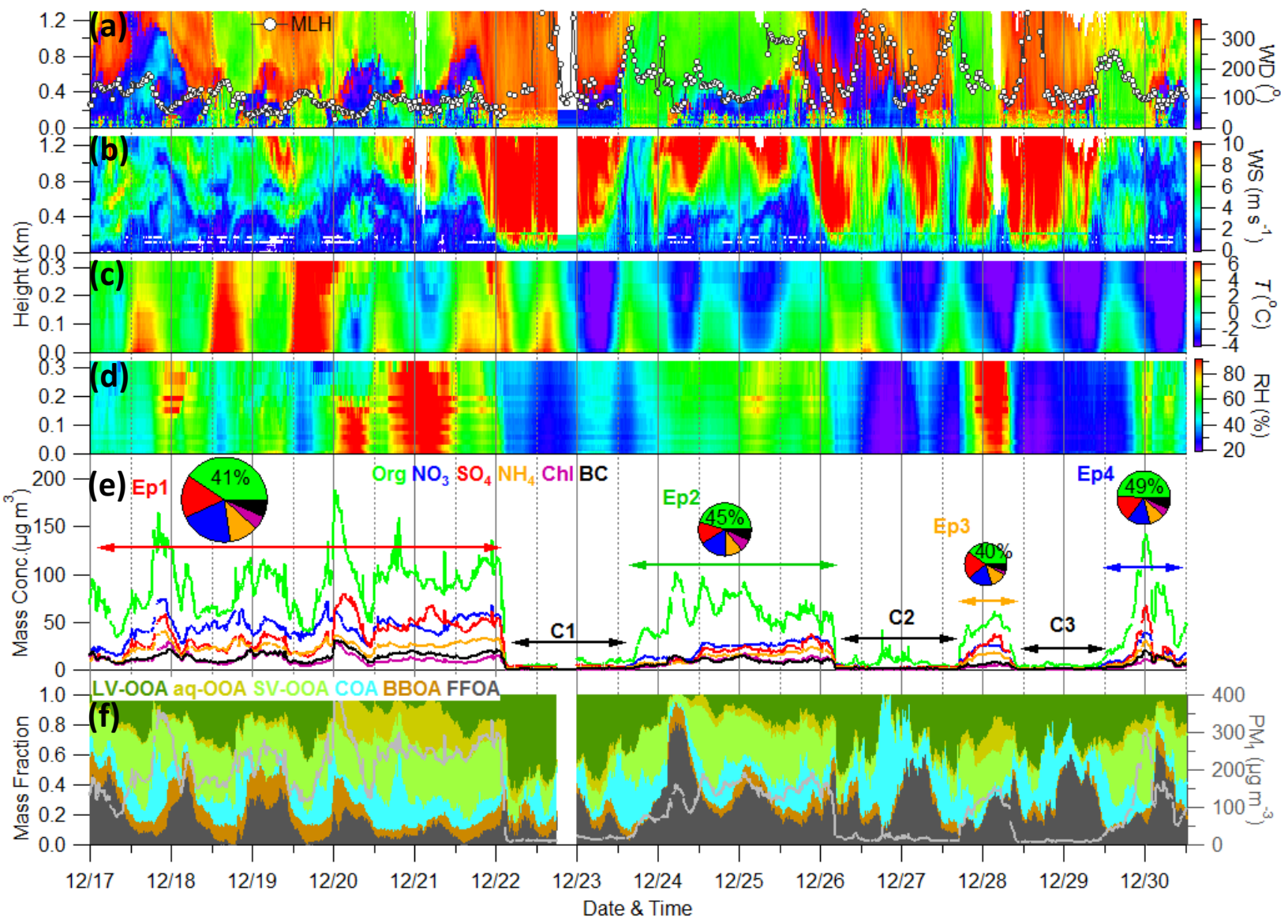


Figure 1. Vertical measurements of (a) wind direction (WD), (b) wind speed (WS), (c) temperature $(T)$ and $(\mathbf{d})$ relative humidity $(\mathrm{RH})$; (e) time series of $\mathrm{NR}-\mathrm{PM}_{1}$ species measured by AMS and BC, and (f) mass fraction of OA factors and time series of total $\mathrm{PM}_{1}$ (gray line) during the entire study. Mixing layer height (MLH) is given in panel (a). The pie charts show the average chemical compositions of $\mathrm{PM}_{1}$ for four polluted episodes (i.e. Ep1-Ep4).

Figure 1 shows the time series of meteorological parameters and $\mathrm{PM}_{1}$ species during 17-30 December in 2016. The total $\mathrm{PM}_{1}$ varied dramatically with an average $( \pm 1 \sigma)$ mass loading of $126.7( \pm 96.2) \mu \mathrm{g} \mathrm{m}^{-3}$. Consistent with previous studies (Chen et al., 2015; Sun et al., 2014;Sun et al., 2016a), the formation of haze episodes was associated with a wind direction change from the north-northwest-northeast to the south, while the clean events were characterized by prevailing northerly flow air masses with high wind speed $\left(>4 \mathrm{~m} \mathrm{~s}^{-1}\right.$ ) (Figure S10). In total, four haze episodes (Ep1, Ep2, Ep3, and Ep4) and three clean events (C1, C2, C3) were observed throughout the study. The average $\mathrm{PM}_{1}$ concentrations during four haze episodes ranged from 109 to $216 \mu \mathrm{g} \mathrm{m}^{-3}$ (Table S3), which are much higher than the National Ambient Air Quality Standard for $\mathrm{PM}_{2.5}$ (75 $\mu \mathrm{g} \mathrm{m}^{-3}$ for the daily average). In particular, the first haze episode, Ep1, showed consistently high $\mathrm{PM}_{1}$ mass concentrations for more than five days in spite of the "red alert" from the Beijing government and subsequent strict emission controls during this period. Such a long haze episode was also observed in the winter of 2015 (Sun et al., 2016a), which was mainly associated with stagnant meteorological conditions with low wind speed $\left(<2 \mathrm{~m} \mathrm{~s}^{-1}\right)$ and MLH ( $400 \mathrm{~m}$ for most of the time), enhanced secondary aerosol formation, and regional transport.

OA constituted the largest fraction of $\mathrm{PM}_{1}$ during both polluted (40-49\%) and clean (44-50\%) periods, yet the composition was substantially different. For example, the contributions of BBOA and SV-OOA to OA were much higher during haze episodes (10\% vs. $4 \%$ and $32 \%$ vs. $11 \%$ ), while COA and LV-OOA were more dominant during clean events (26\% vs. $13 \%$ and $36 \%$ vs. $16 \%$ ). Higher contributions of aq-OOA were also observed during haze episodes with higher RH than clean periods (10\% vs. 3\%). These results suggest largely different sources and chemical processing of OA under different pollution levels.

On average, OA accounted for $45 \%$ of $\mathrm{NR}-\mathrm{PM}_{1}$, consistent with previous AMS measurements in winter (Hu et al., 2016;Sun et al., 2013b;Wang et al., 2015;Sun et al., 2014;Zhang et al., 
2014;Sun et al., 2016b;Zhang et al., 2016) (Figure S11, Table S4) showing ubiquitous dominance of organics (42-59\%). This highlights the importance of OA in particulate matter pollution in Beijing in winter. SOA accounted for $58 \%$ of the OA with SV-OOA being the

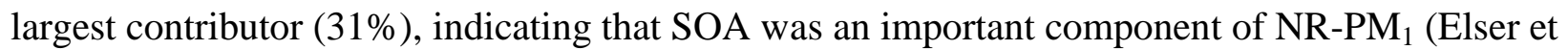
al., 2016; Huang et al., 2014;Sun et al., 2014;Xu et al., 2019). Indeed, SOA was comparable to the SIA $\left(=\mathrm{SO}_{4}{ }^{2-}+\mathrm{NO}_{3}{ }^{-}+\mathrm{NH}_{4}{ }^{+}\right)$in Beijing in winter during the past several years (SOA/SIA $=$ 0.37 - 0.89). Among POA factors, FFOA contributed the largest fraction of OA (18\%), followed by COA (14\%) and BBOA (10\%). Although SOA dominated OA throughout the study, POA showed largely elevated contributions up to $60 \%$ at night (Figure 1), indicating that local primary emissions were very important sources of haze pollution at night. For example, the traffic-related POA showed much higher concentrations at nighttime than daytime because diesel trucks and heavy-duty vehicles are only allowed to enter the city center between 23:00 - 6:00 (Sun et al., 2016b).

\subsection{Investigation of OA Components and Sources}

\subsubsection{Primary OA}

The FFOA spectrum was characterized by $\mathrm{C}_{\mathrm{n}} \mathrm{H}_{2 \mathrm{n}-1}{ }^{+}$and $\mathrm{C}_{\mathrm{n}} \mathrm{H}_{2 \mathrm{n}+1}{ }^{+}(27,29,41,43,55,57 \ldots)$ and highly correlated with PAHs fragments at $m / z 152,165,178,189$, and 202 (Figure S6). FFOA is a mix of coal-combustion CCOA and traffic-related HOA in this study because PMF was unable to separate these two factors due to their similar spectral patterns and temporal variations. It is likely that coal combustion emissions contributed more than traffic to FFOA due to the reduced number of vehicles during the "red alert" control period. This conclusion was supported by a higher spectral similarity between FFOA and previously reported CCOA $\left(r^{2}=0.86\right)$ than HOA $\left(r^{2}=0.69\right.$, Table $\left.\mathrm{S} 1\right)$. The COA spectrum was characterized by higher $f_{55} / f_{57}$ ratio than FFOA (2.0 vs. 0.9) (Mohr et al., 2012), and the spectral pattern was relatively constant among different years $\left(r^{2}=0.82-0.94\right.$; Table S1), suggesting that cooking styles remained consistent during the last decade. $\mathrm{COA}$ was well correlated with the specific ions $\mathrm{C}_{6} \mathrm{H}_{10} \mathrm{O}^{+}\left(r^{2}=0.69\right)$ and $\mathrm{C}_{5} \mathrm{H}_{8} \mathrm{O}^{+}$ $\left(r^{2}=0.57\right.$, Figure S6), consistent with Sun et al. (2011b) and Ge et al. (2012). The BBOA spectrum was also similar to those previously reported $\left(r^{2}=0.46-0.75\right)$, with pronounced peaks at $m / z 60\left(\mathrm{C}_{2} \mathrm{H}_{4} \mathrm{O}_{2}{ }^{+}\right)$and $m / z 73\left(\mathrm{C}_{3} \mathrm{H}_{5} \mathrm{O}_{2}{ }^{+}\right)$, which are well known biomass-burning markers from anhydrosugar compounds (Lanz et al., 2007; Alfarra et al., 2007;Mohr et al., 2012). In addition, 
253 clear PAHs fragments are evident in the unit mass resolution (UMR) mass spectrum of BBOA 254 (Figure S5), indicating that biomass burning is also an important source of PAHs in winter in 255 Beijing (Elser et al., 2016;Sun et al., 2016b).

256 Although air quality in Beijing has improved significantly in recent years, FFOA was still the 257 most important primary source in winter during this study, with the contributions to OA ranging 258 from $19 \%$ to $50 \%$. The FFOA concentrations have also varied significantly in recent years, from $2596.3 \mu \mathrm{g} \mathrm{m}^{-3}$ to $18.8 \mu \mathrm{g} \mathrm{m}^{-3}$ (Figure S11). One reason is the influence of BBOA, which was not 260 separated from coal combustion in previous studies with measurements from quadrupole aerosol 261 chemical speciation monitor, leading to an overestimation of FFOA by $44-50 \%$ (Sun et al., 262 2013b;Wang et al., 2015;Zhang et al., 2016). Another reason is likely the influence of regional 263 transport from the south and southwest of Beijing, where raw coal is still used for residential 264 heating. The contribution of BBOA to OA has been relatively stable during the past several years, 265 constituting about $10 \%$ of the OA, with mass concentrations ranging from 3.3 to $5.2 \mu \mathrm{g} \mathrm{m}^{-3}$. 266 However, higher BBOA contributions were also observed during extreme haze episodes (14\%) 267 than clean periods (9\%) (Elser et al., 2016). The contributions of COA to OA were comparably 268 stable (14-20\%), and the average mass concentration was $\sim 7 \mu \mathrm{g} \mathrm{m}^{-3}$ except a low value $(3.8 \mu \mathrm{g}$ $269 \mathrm{~m}^{-3}$ ) in January 2014 (Zhang et al., 2015). This indicates relatively stable contributions of COA 270 and BBOA to air pollution in winter in Beijing in recent years. 

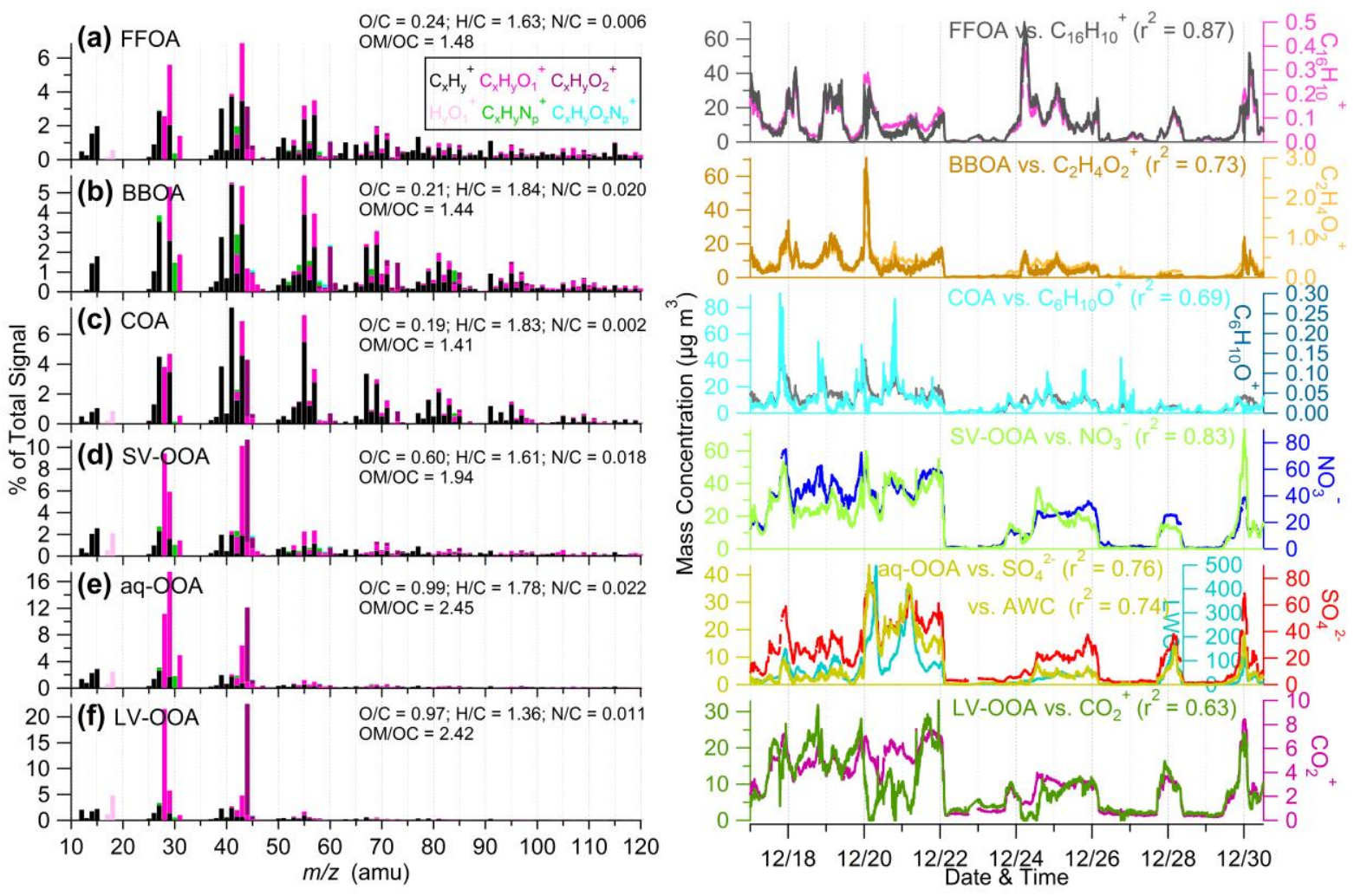

Figure 2. Mass spectra (left panel) and time series (right panel) of six OA factors. The time series of specific fragment ions, inorganic species and external tracers are also given in the right panel for comparisons.

\subsubsection{Secondary Organic Aerosols}

Consistent with previously reported SOA at urban sites (DeCarlo et al., 2010;Sun et al., 2011b;Xu et al., 2015), SV-OOA and LV-OOA have prominent signals at $m / z 44\left(\mathrm{CO}_{2}{ }^{+}\right)$, and LV-OOA has a higher O/C than SV-OOA (0.97 vs. 0.60). SV-OOA correlates with nitrate $\left(r^{2}=0.83\right)$ due to their similar semi-volatile nature and formation pathways, whereas LV-OOA correlates with $\mathrm{CO}_{2}{ }^{+}\left(r^{2}=0.63\right)$. On average, the contribution of SV-OOA to OA (31\%) was nearly twice that of LV-OOA (17\%). However, the contribution of SV-OOA to OA was higher than that of LV-OOA ( $28-34 \%$ vs. $12-25 \%)$ during haze episodes, while LV-OOA was more important than SV-OOA during clean periods (36\% vs. 11\%). This suggests very different chemical processing of SOA under different pollution levels (Table S2).

285 The aq-OOA factor showed high concentrations (up to $40 \mu \mathrm{g} \mathrm{m}^{-3}$ ) during periods with high $\mathrm{RH}$ 286 (for example, 0:00-12:00, 20 December, and 20:00 27 to 09:00 28 December in Figure 1), 
indicating that it was either formed via aqueous-phase reactions or absorbed/dissolved into aerosol liquid water. The fact that aq-OOA correlates well with sulfate $\left(r^{2}=0.76\right)$ and AWC $\left(r^{2}=0.74\right)$ supports this hypothesis (Gilardoni et al., 2016). The mass spectrum of aq-OOA in this study resembles previously reported aq-OOA in Beijing (Sun et al., 2016b;Xu et al., 2019), which was dominated by peaks at $m / z 29\left(\mathrm{CHO}^{+}\right), m / z 43\left(\mathrm{C}_{2} \mathrm{H}_{3} \mathrm{O}^{+}\right)$, and $m / z 44\left(\mathrm{CO}_{2}{ }^{+}\right)$. However, the spectral patterns also showed differences and the $\mathrm{O} / \mathrm{C}$ ratios varied substantially from 0.62 to 0.99. These results indicate that the specific composition of SOA related to aqueous-phase processes could vary with differences in $\mathrm{RH}$ and precursor concentrations. For example, aq-OOA identified in the Po Valley shows much higher $\mathrm{m} / \mathrm{z} 44$ in the spectrum at rural site than urban site (Gilardoni et al., 2016). In this study, aq-OOA on average accounted for $10 \%$ of the total OA, which is comparable to those reported in previous studies in Beijing (13 - 17\%) (Sun et al., 2016b; Xu et al., 2019). However, aq-OOA showed elevated contributions up to $35 \%$ during periods with high RH levels (>90\%), highlighting the significantly enhanced formation of aqOOA at high RH.

\subsection{Water-soluble OA}

Figure 3 shows a comparison of elemental and ion composition between total $\mathrm{OA}$ in $\mathrm{PM}_{1}$ and WSOA in $\mathrm{PM}_{2.5}$. WSOA in $\mathrm{PM}_{2.5}$ comprised consistently higher fractions of $\mathrm{N}$ - and S-containing ions $\left(\mathrm{C}_{\mathrm{x}} \mathrm{H}_{\mathrm{y}} \mathrm{N}_{\mathrm{p}}{ }^{+}, \mathrm{C}_{\mathrm{x}} \mathrm{H}_{\mathrm{y}} \mathrm{O}_{\mathrm{z}} \mathrm{N}_{\mathrm{p}}{ }^{+}\right.$and $\left.\mathrm{C}_{\mathrm{x}} \mathrm{H}_{\mathrm{y}} \mathrm{O}_{\mathrm{z}} \mathrm{S}_{\mathrm{q}}{ }^{+}\right)$than the total OA in $\mathrm{PM}_{1}$ (8.3-12.6\% vs. $2.9-$ $5.9 \%)$. Similarly, high fractions of N- and S-containing compounds were also observed in WSOA in southeastern US (Sun et al., 2011a) and fog water in Fresno (Kim et al., 2019). Our previous study showed that LV-OOA and BBOA are two most important contributors of organic nitrogen in OA in winter (Xu et al., 2017c), and also have high water-solubility (Qiu et al., 2019), which explain high $\mathrm{N}$-containing compounds in WSOA. The relatively high water-soluble fraction of BBOA and LV-OOA were also reported in rural and urban environments in the US (Xu et al., 2017a). Compared to the total OA, WSOA showed higher contributions of $\mathrm{C}_{\mathrm{x}} \mathrm{H}_{\mathrm{y}} \mathrm{O}_{2}{ }^{+}$ $(14-22 \%$ vs. $10-18 \%)$, while that of $\mathrm{C}_{\mathrm{x}} \mathrm{H}_{\mathrm{y}} \mathrm{O}_{1}{ }^{+}$was comparable $(26-33 \%$ vs. $24-36 \%)$. These results indicate that WSOA comprised more oxygenated organic compounds during haze episodes, consistent with ubiquitously higher O/C ratios of WSOA than the total OA. 

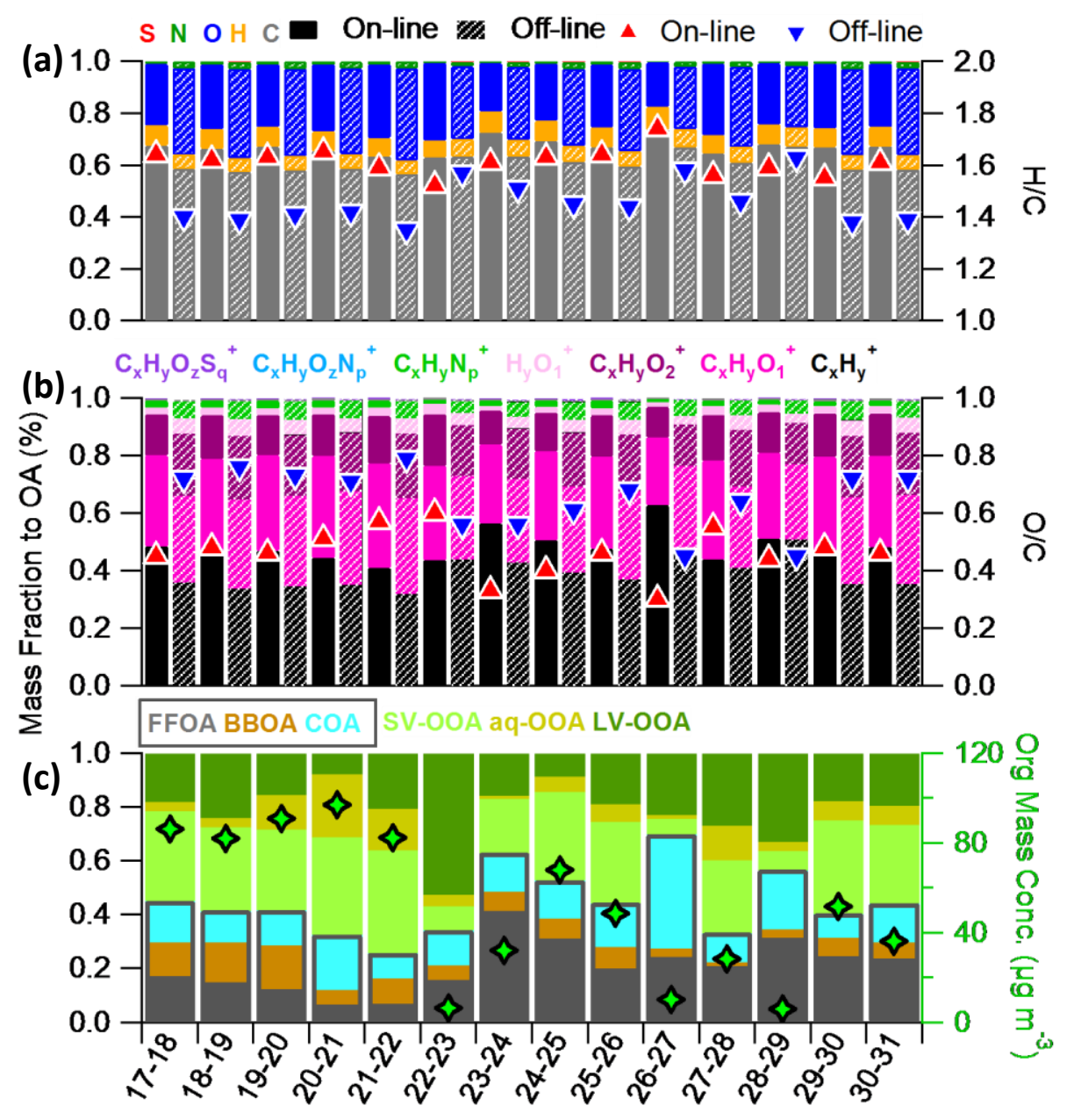

December 2016

316 Figure 3. Daily average composition of (a) elements $(\mathrm{C}, \mathrm{H}, \mathrm{O}, \mathrm{N}$, and $\mathrm{S})$, and (b) ion families of total OA in $\mathrm{PM}_{1}$ (on-line) and WSOA in $\mathrm{PM}_{2.5}$ (off-line). (c) shows average OA composition from $\mathrm{PMF}$ analysis. The average $\mathrm{H} / \mathrm{C}, \mathrm{O} / \mathrm{C}$ ratios, and organic mass concentrations are also 319 shown as colored markers.

We further compared the mass spectra of WSOA and total OA under different pollution levels

321 (Figure 4). Higher contributions of $\mathrm{C}_{\mathrm{x}} \mathrm{H}_{\mathrm{y}} \mathrm{O}_{2}{ }^{+}$were observed in WSOA $(17.5-22.3 \%)$ than the 322 total OA (11.8-16.3\%) in polluted days, whereas the contributions of $\mathrm{C}_{\mathrm{x}} \mathrm{H}_{\mathrm{y}}{ }^{+}$in WSOA were 323 correspondingly lower $(32.0-48.0 \%$ vs. $41.0-56.4 \%)$. As a result, higher $\mathrm{O} / \mathrm{C}$ ratios $(0.56-$ 3240.79 vs. $0.33-0.57)$ and lower $\mathrm{H} / \mathrm{C}$ ratios $(1.35-1.51$ vs. $1.55-1.65)$ in WSOA than OA were 325 observed. In contrast, $\mathrm{C}_{\mathrm{x}} \mathrm{H}_{\mathrm{y}} \mathrm{O}_{2}{ }^{+}$and $\mathrm{C}_{\mathrm{x}} \mathrm{H}_{\mathrm{y}}{ }^{+}$showed comparable contributions between WSOA and $\mathrm{OA}$ during clean days, and the $\mathrm{O} / \mathrm{C}$ and $\mathrm{H} / \mathrm{C}$ ratios were also similar. A possible explanation is 
the high contribution of LV-OOA with high water-solubility during clean days. Note that the spectral patterns of WSOA were all similar during clean days, while that of OA can be substantially different due to the influences of COA. For example, OA on the clean day of $26-$ 27 December showed a large contribution of COA (42\%), and the OA spectrum was characterized by high $f_{55} / f_{57}$ and low $\mathrm{O} / \mathrm{C}(0.30)$ (Figure $4 \mathrm{e}$ ), while that of WSOA presented much higher $\mathrm{O} / \mathrm{C}(0.45)$. These results were consistent with the low water solubility of COA (Qiu et al., 2019;Xu et al., 2017a).

(a)

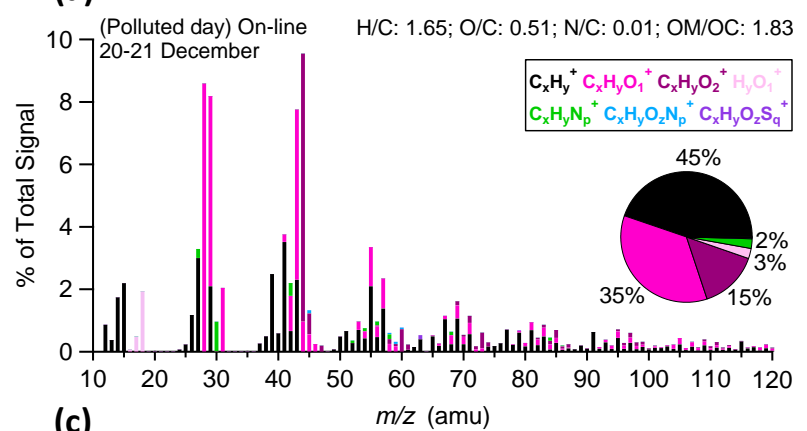

$$
\text { (c) }
$$

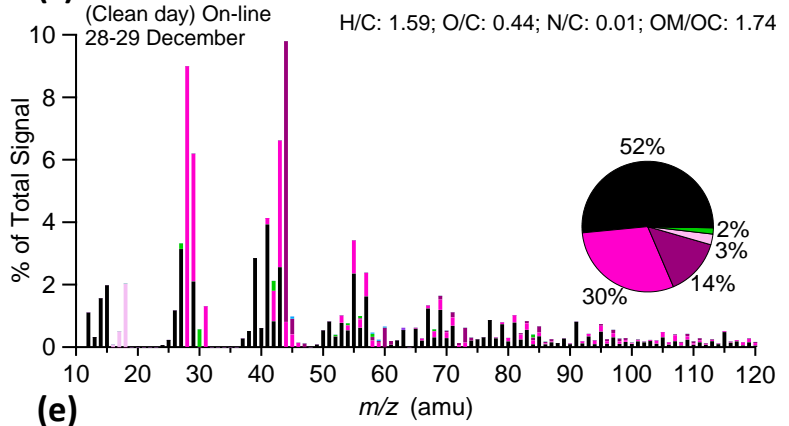

(e)

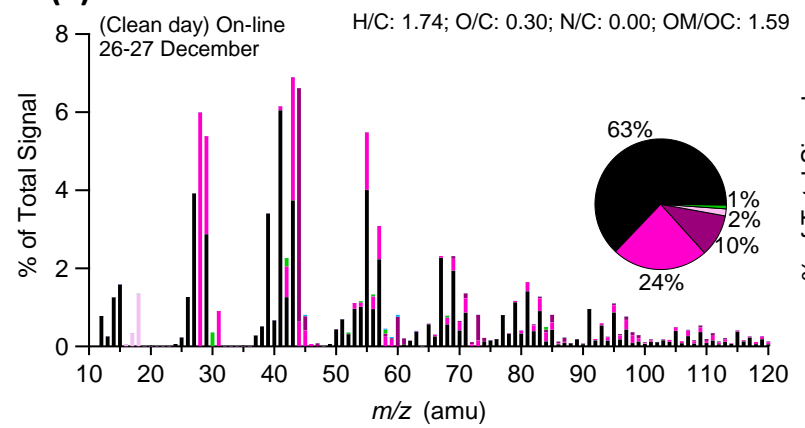

(b)

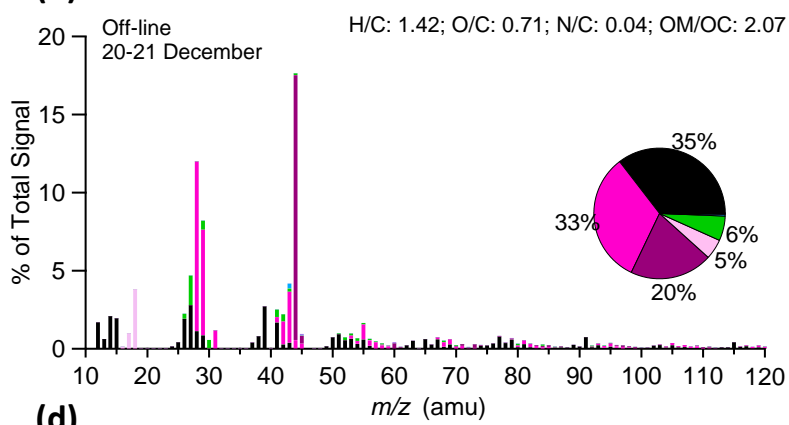

14 Off-line H/C: 1.64 ; O/C: 0.45 ; N/C: 0.02 ; OM/OC: 1.77
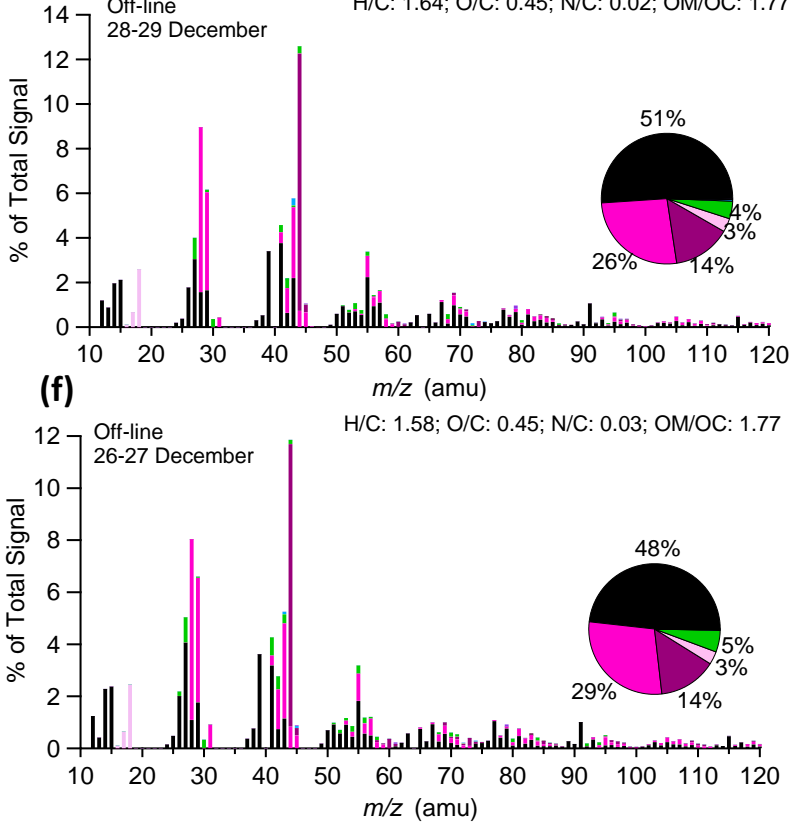

Figure 4. Comparisons of high-resolution mass spectra of the total $\mathrm{OA}$ in $\mathrm{PM}_{1}$ (on-line measurements) and WSOA in $\mathrm{PM}_{2.5}$ (off-line measurements) during a polluted day (a,b) 20 - 21 December (Ep1) and two clean days (c,d) 28 - 29 December (C3), and (e,f) 26 - 27 December (C2). The average contributions of ion families for each mass spectra are also given in pie charts. 

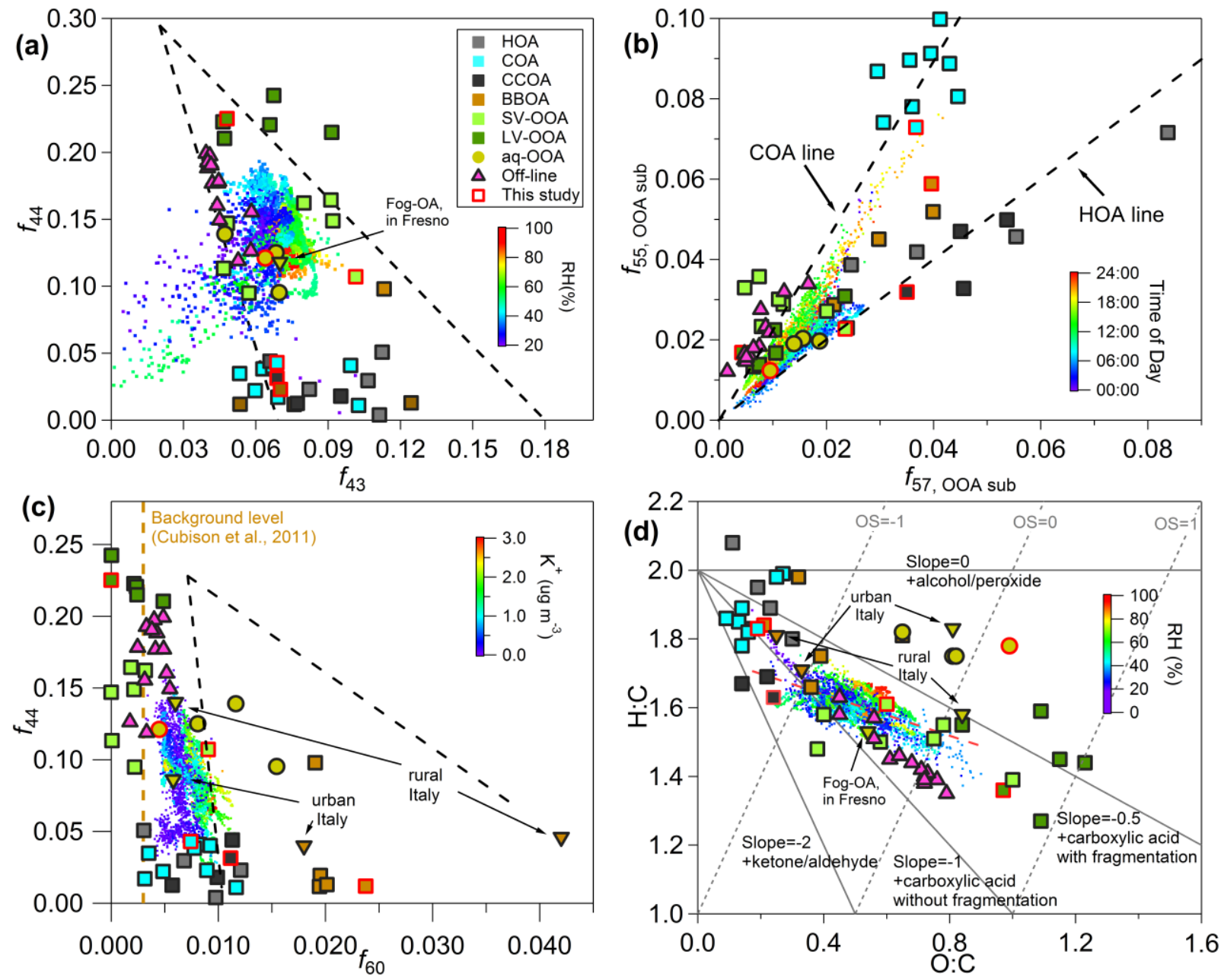

Figure 5. Triangle plots of (a) $f_{44}$ vs. $f_{43}$, the dash lines were adopted from Ng et al. (2010), (b)

$343 f_{55}$ vs. $f_{57}$, the dash lines defined a specific "V" shape which were adopted from Mohr et al.

344 (2012), (c) $f_{44}$ Vs. $f_{60}$, the background level (brown dashed line) and black dashed "V" shape

345 guide line were adopted from Cubison et al. (2011), and (d) Van Krevelen Diagram (Heald et al., 346 2010). The data points in the figure included the measurements in this study (colored dots) and 347 previous AMS measurements at the same site, i.e., winter 2013 (Sun et al., 2016b), summer 2014 348 (Xu et al., 2017b), fall 2014 (Xu et al., 2015), winter 2014 (Xu et al., 2019), fall 2015 (Zhao et 349 al., 2017) and winter 2016 (Xu et al., 2019). The aq-OOA identified in San Joaquin Valley, 
Fresno, California (Kim et al., 2019) and Italy (Gilardoni et al., 2016) are also given for comparisons. Note that the contributions of OOA factors to $f_{55}$ and $f_{57}$ in (b) were subtracted. The triangle plot of $f_{44}$ vs. $f_{43}$ has been widely used to characterize OA evolution in the atmosphere because $m / z$ 's 44 and 43 are usually from different functional groups and the ratio changes as a function of atmospheric aging. As shown in Figure 5a, POA and SOA factors in different seasons of different years overall fell into similar regions of $f_{44} \mathrm{vs.} f_{43}$, suggesting that OA factors identified by PMF were fairly similar in urban Beijing across different years. The bottom region of the triangle was dominated by POA factors (i.e. HOA, COA, CCOA, and BBOA) with low $f_{44}(<0.051)$ and a wide range of $f_{43}$ up to 0.13 , indicating that they were freshly emitted and less oxidized.

Comparatively, SOA factors are located in two distinct regions: 1) LV-OOA region, with much higher $f_{44}(>0.21)$ than other OA factors, consistent with the fact that LV-OOA is a surrogate of highly oxidized or regionally transported SOA (Aiken et al., 2009;Ulbrich et al., 2009;DeCarlo et al., 2010); and 2) SV-OOA and aq-OOA region, showing freshly oxidized properties $\left(f_{44}=\right.$ $0.09-0.16$ ). In fact, all aq-OOA factors are located in a similar region with the fog-related factor (F-OA) and interstitial OA observed in Fresno, California by Kim et al. (2019) in both UMR and HR triangle plots (Figure S12a), which supports the presence of aqueous-phase related processing under high $\mathrm{RH}$ conditions. Note that, aq-OOA is difficult to be separated from SVOOA in this triangle plot and thus falls in a class of less oxidized OOA factors, in this case formed through aqueous-phase related processing instead of photochemical reactions. Further aging of aq-OOA and SV-OOA could form LV-OOA, and this region will move towards left-top associated with increases in $f_{44}$ and corresponding decreases in $f_{43}$ (Jimenez et al., 2009; Hildebrandt et al., 2010; Sun et al., 2011b). In addition, WSOA showed a wide range of $f_{44}$ $(0.12-0.20)$ suggesting the influences of multiple sources on WSOA. The differences of WSOA and aq-OOA in $f_{44}$ vs. $f_{43}$ indicate that a considerable fraction of WSOA was not from aqueousphase processing.

\subsection{2 $f_{55}$ vs. $f_{57}$}

The plot of $f_{55}$ vs. $f_{57}$ can be used as a diagnostic for separating HOA from COA (Mohr et al., 2012). As shown in Figure 5b, HOA and COA can be well separated from each other along the well-defined "V" shape. All COA factors are characterized by high $f_{55}(0.073-0.10)$ (He et al., 
2010;Mohr et al., 2012;Kaltsonoudis et al., 2017) falling into the top part of "COA line" with similar $f_{57}(0.030-0.045)$ despite different types of COA (Xu et al., 2015; Xu et al., 2017b). Similarly, OA during the periods with significant influences of cooking (12:00 - 14:00 and 18:00 $-22: 00$, colored dots) also varied along the "COA line".

Although HOA shows a wide range of $f_{55}(0.039-0.072)$ and $f_{57}(0.025-0.084)$, the ratios of $f_{55} / f_{57}$ were fairly constant and fell near the "HOA line". The observed nighttime data points (0:00 - 06:00) varied along the "HOA line" throughout the study, consistent with the fact that heavy-duty diesel trucks can only enter the urban area of Beijing between 23:00 and 6:00 (Han et al., 2009; Huang et al., 2010). In addition, CCOA also falls near "HOA line", confirming that CCOA and HOA have similar spectral patterns and sometimes can be challenging to separate from each other in winter in Beijing (Zhang et al., 2016). BBOA factors can be separated from HOA and COA, falling into the middle region of the "V" shape, while SOA factors and WSOA show small values of both $f_{55}$ and $f_{57}$ and thus are located the left-bottom region.

\subsection{3 $f_{44}$ vs. $f_{60}$}

$f_{44}$ vs. $f_{60}$ or $f_{\mathrm{CO}_{2}^{+}}$vs. $f_{\mathrm{C}_{2} \mathrm{H}_{4} \mathrm{O}_{2}^{+}}$is commonly used to investigate the aging trend of $\mathrm{BBOA}$ in the atmosphere (Cubison et al., 2011). The BBOA factors in Beijing are all located in the low right region in Figure $5 \mathrm{c}$ showing much higher $f_{60}(0.019-0.024)$ than other POA factors $(0.003-$ 0.012). The bulk OA measured in this study also showed ubiquitously higher $f_{60}$ than $0.3 \%$, a typical value in the absence of biomass-burning impacts (Cubison et al., 2011). Furthermore, higher $f_{60}$ values are associated with higher mass concentrations of potassium $\left(\mathrm{K}^{+}\right)$, another potential tracer of biomass burning. This suggests ubiquitous biomass burning impacts on OA in winter in Beijing (Li et al., 2018).

The aq-OOA factors we identified in Beijing show similarly high $f_{60}$ levels as aqueous phase SOA (aqSOA) observed at rural and urban sites in Italy (Gilardoni et al., 2016), suggesting that aqueous formed SOA could be from chemical processing of biomass-burning aerosols. In contrast, $f_{60}$ in LV-OOA and SV-OOA was overall close to the background value of $\sim 0.3 \%$, indicating different sources and/or loss the signatures of BBOA (Jimenez et al., 2009). In addition, we observed higher $f_{60}$ than $0.3 \%$ for most WSOA samples, consistent with the considerable water solubility of BBOA reported in previous studies (Qiu et al., 2019; Xu et al., 2017a). 


\subsubsection{Van Krevelen (VK) Diagram}

The OA evolution in winter in Beijing is further analyzed by Van Krevelen (VK) diagram in Figure 5d (Heald et al., 2010). The majority of the data points show similar evolutionary trends with previous measurements, i.e., POA factors are located at the left-top corner with high H/C, low $\mathrm{O} / \mathrm{C}$ and $\overline{\mathrm{OS}} c$ below -1 , and then evolve towards the right-bottom by forming SOA (Kroll et al., 2011). As organic compounds are oxidized, the products advance along various lines in the VK diagram depending on added functional groups. Net addition of only oxygen atoms to a carbon backbone results in slope equal zero, while the replacement of a hydrogen atom with a carboxylic acid group $(-\mathrm{COOH})$ results in a slope of -1 without fragmentation $(\mathrm{C}-\mathrm{C}$ bond breaking), and -0.5 with fragmentation ( $\mathrm{Ng}$ et al., 2011b;Heald et al., 2010). A relatively flat slope of -0.3 for $\mathrm{H} / \mathrm{C}$ vs. $\mathrm{O} / \mathrm{C}$ in this study suggests the importance of addition of alcohol and/or peroxide (slope $=0$ ) in OA aging with additional processes adding carboxylic acid and/or carboxyl groups.

The aq-OOA factors are located near upper right region with both high $\mathrm{O} / \mathrm{C}$ and $\mathrm{H} / \mathrm{C}$ values, which is different from the other SOA factors. As shown in Figure 2, aq-OOA shows higher $f_{\mathrm{CHO}^{+}}$and lower $f_{\mathrm{CO}_{2}^{+}}$than other SOA factors (Fig. S13), indicating their different compositions and formation processes. Similarly, the evolution pathway from BBOA to aqSOA was reported with the slope near zero in rural Italy (Gilardoni et al., 2016), which might indicate the potential contribution from BBOA and formation of hydroxyl group through dark chemistry (Lim et al., 2010). This was further supported by the increasing signal at $m / z 29$ (mainly $\mathrm{CHO}^{+}$) as a function of RH (Figure 6b). In addition, a BBOA factor located in the similar region with aq-OOA factors further revealed that aq-OOA might have a great influence from BBOA.

\subsection{Aqueous Phase-Related Chemical/Physical Processes}

Figure 6a shows that the molar ratio of sulfate to $\mathrm{SO}_{2}$ increased substantially as a function of $\mathrm{RH}$ during Ep1, which is consistent with previously reported rapid formation of sulfate during high RH conditions (Wang et al., 2016). However, we also found large increases in mass ratios of fragments $\mathrm{SO}_{2}{ }^{+}$to $\mathrm{SO}_{3}{ }^{+}$at high $\mathrm{RH}$ levels, while those of $\mathrm{SO}_{2}{ }^{+}$to $\mathrm{SO}^{+}$were relatively stable. Considering that fragmentation of organosulfur compounds mainly produces $\mathrm{SO}^{+}$and $\mathrm{SO}_{2}{ }^{+}$with negligible $\mathrm{SO}_{3}{ }^{+}$(Ge et al., 2012; Gilardoni et al., 2016), the increases in $\mathrm{SO}_{2}{ }^{+} / \mathrm{SO}_{3}{ }^{+}$are in the very least consistent with formation of organosulfur compounds in addition to the enhanced aqueous 
440 formation of sulfate at high RH (Sun et al., 2016b;Song et al., 2019). The presence of

441 organosulfur compounds (OS) was further supported by the triangle plot of $f_{\mathrm{H}_{2} \mathrm{SO}_{4}^{+}}$vs. $f_{\mathrm{HSO}_{3}^{+}}$

442 (fractions of $\mathrm{H}_{2} \mathrm{SO}_{4}{ }^{+}$and $\mathrm{HSO}_{3}{ }^{+}$in $\mathrm{HSO}\left(=\mathrm{SO}^{+}+\mathrm{SO}_{2}{ }^{+}+\mathrm{SO}_{3}{ }^{+}+\mathrm{HSO}_{3}{ }^{+}+\mathrm{H}_{2} \mathrm{SO}_{4}{ }^{+}\right)$) proposed by

443 Chen et al. (2019). By analyzing the fragmentation patterns of different types of S-containing

444 standards including ammonium sulfate (AS), sodium sulfate (SS), methanesulfonic acid (MSA),

445 and OS compounds, Chen et al. (2019) found that the $\mathrm{H}_{2} \mathrm{SO}_{4}{ }^{+}$fragment was exclusively from AS,

446 while $\mathrm{HSO}_{3}{ }^{+}$was comparably from both AS and MSA. In contrast, OS and SS produced

447 negligible fragments of $\mathrm{HSO}_{3}{ }^{+}$and $\mathrm{H}_{2} \mathrm{SO}_{4}{ }^{+}$. As shown in Figure 6(c), the $f_{\mathrm{H}_{2} \mathrm{SO}_{4}^{+}}$vs. $f_{\mathrm{HSO}_{3}^{+}}$

448 evolved towards the left-bottom OS region as RH increased during this period, supporting the 449 presence of OS and MSA during periods with high RH. We then estimated the contribution of 450 OS and MSA to the total sulfates using the method in Chen et al. (2019) by assuming that (1) the 451 contribution of SS was negligible in this study because our sampling site is far from the ocean, (2) $452 f_{\mathrm{HSO}_{3}^{+}}$of MSA was assumed to be 0.07 which was slightly higher than that of AS (0.064) since 453 MSA was not calibrated. Our results showed that OS and MSA on average contributed 19\% and $4544.6 \%$ to the total HSO during Ep1, supporting a considerable amount of OS in aerosol particles 455 during this study. The results are also consistent with a recent study showing that OS on average 456 contributed $17 \pm 7 \%$ of AMS sulfate during Chinese winter haze events, and the majority of OS 457 could be hydroxymethane sulfonate from heterogeneous reactions of $\mathrm{SO}_{2}$ and formaldehyde 458 (Song et al., 2019). In addition, higher contributions N- and S-containing peaks were observed in 459 the mass spectra during higher RH periods (Figure S15), indicating the potential formation of N460 and S-containing organic compounds under high RH conditions (Kim et al., 2019; Setyan et al., 461 2019). 


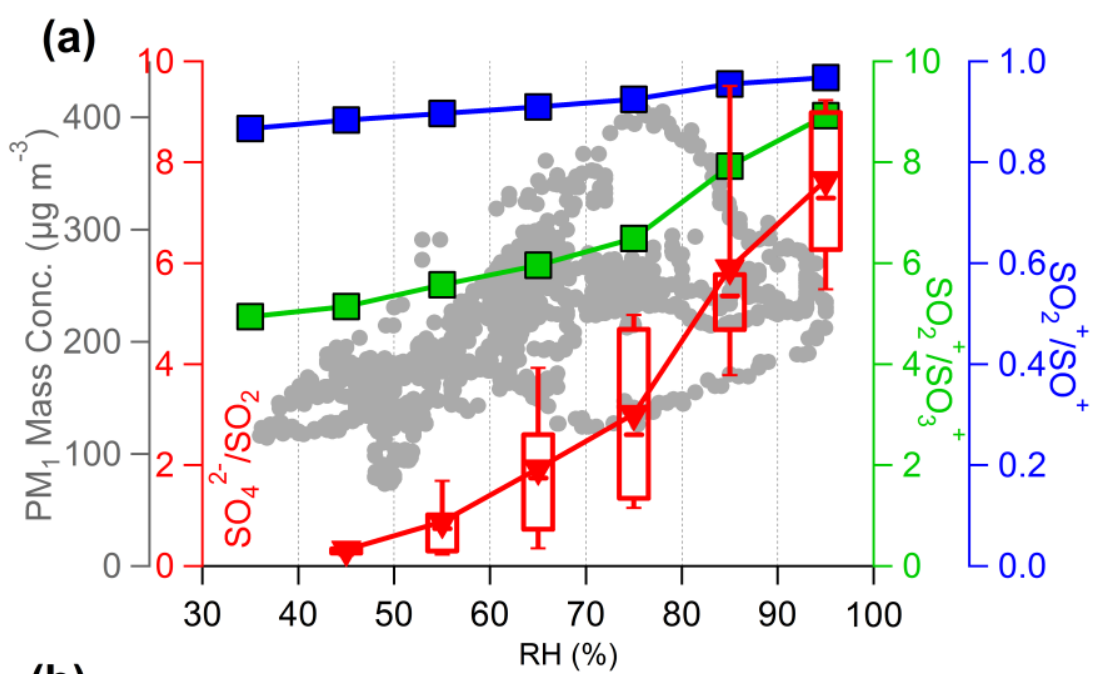

(b)

LV-OOA aq-OOA SV-OOA COA BBOA FFOA
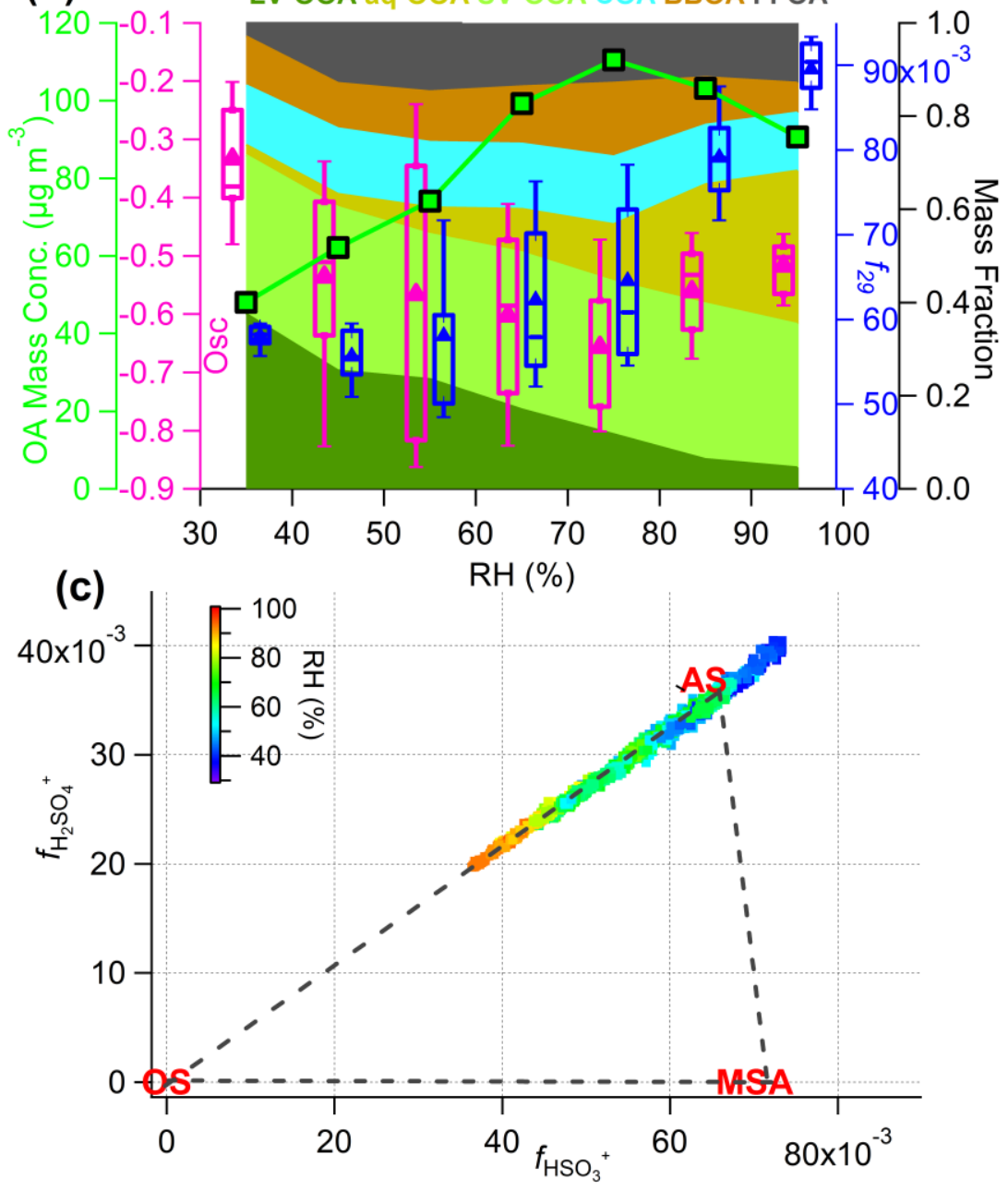

463 Figure 6. Variations of (a) $\mathrm{PM}_{1}$ mass concentrations, molar ratios of particulate sulfate to

464 gaseous $\mathrm{SO}_{2}\left(\mathrm{SO}_{4}{ }^{2-} / \mathrm{SO}_{2}\right)$, mass ratios of $\mathrm{SO}_{2}{ }^{+} / \mathrm{SO}_{3}{ }^{+}$and $\mathrm{SO}_{2}{ }^{+} / \mathrm{SO}^{+}$from PIKA analysis, and (b)

465 OA mass concentrations, carbon oxidation state $(\overline{\mathrm{OS}} c), f_{29}$ and mass fraction of OA factors as a 
466

467

468

469

470

471

472

473

474

475

476

477

478

479

480

481

482

483

484

485

486

487

488

489

490

function of relative humidity $(\mathrm{RH})$ for Ep1. The data are grouped into different bins according to a $10 \%$ increment of RH. Also shown are mean (triangle/square), median (horizontal line), 25th and 75th percentiles (lower and upper box), and 10th and 90th percentiles (lower and upper whiskers). (c) The triangle plot of $f_{\mathrm{H}_{2} \mathrm{SO}_{4}^{+}}$vs. $f_{\mathrm{HSO}_{3}^{+}}$for Ep1. The fragmentation patterns of ammonium sulfate (AS) was obtained from the calibration with pure AS, while the values of organosulfur compounds (OS) and methanesulfonic acid (MSA) was adopted from Chen et al. (2019).

As shown in Figure 6b, the SOA composition changed significantly as the RH increased, although the average contributions of POA and SOA were fairly constant across different RH levels. The aq-OOA factor showed a significant enhancement from less than $3 \%$ at $\mathrm{RH}<40 \%$ to $12-33 \%$ when $\mathrm{RH}>70 \%$, which was associated with a corresponding decrease in LV-OOA. This supports a more intensive formation of aq-OOA than LV-OOA at high RH levels although the transformation of LV-OOA into aq-OOA could be also possible. Indeed, we observed a strong anticorrelation between LV-OOA and aq-OOA during periods with high $\mathrm{RH}(>60 \%)$ in Figure 7a. In Beijing, the periods with low RH were generally characterized by air masses from the north-northwest (Figure S10), which represented a regional source of pollutants and had high values of $\overline{\mathrm{OS}} c$ for bulk OA. When RH increased from $30 \%$ to $70 \%, \overline{\mathrm{OS}} c$ decreased from -0.38 to -0.66 (Figure $6 b$ ), which is consistent with the decrease in mass fraction of LV-OOA. This suggests that LV-OOA contributed substantially to the oxidation state of OA under moderate RH conditions. The changes in $\overline{\mathrm{OS}} c$ were also likely affected by gas-particle partitioning under different OA mass loadings (Odum et al., 1996;Donahue et al., 2006). At low OA levels, highly oxygenated and less volatile organic compounds are favored to partition into aerosol phase, resulting in relatively high $\overline{\mathrm{OS}} c$ values, while at high OA levels less-oxygenated and semivolatile species could also condense efficiently onto preexisting particles, leading to a decreasing trend of $\overline{\mathrm{OS}} c$. 

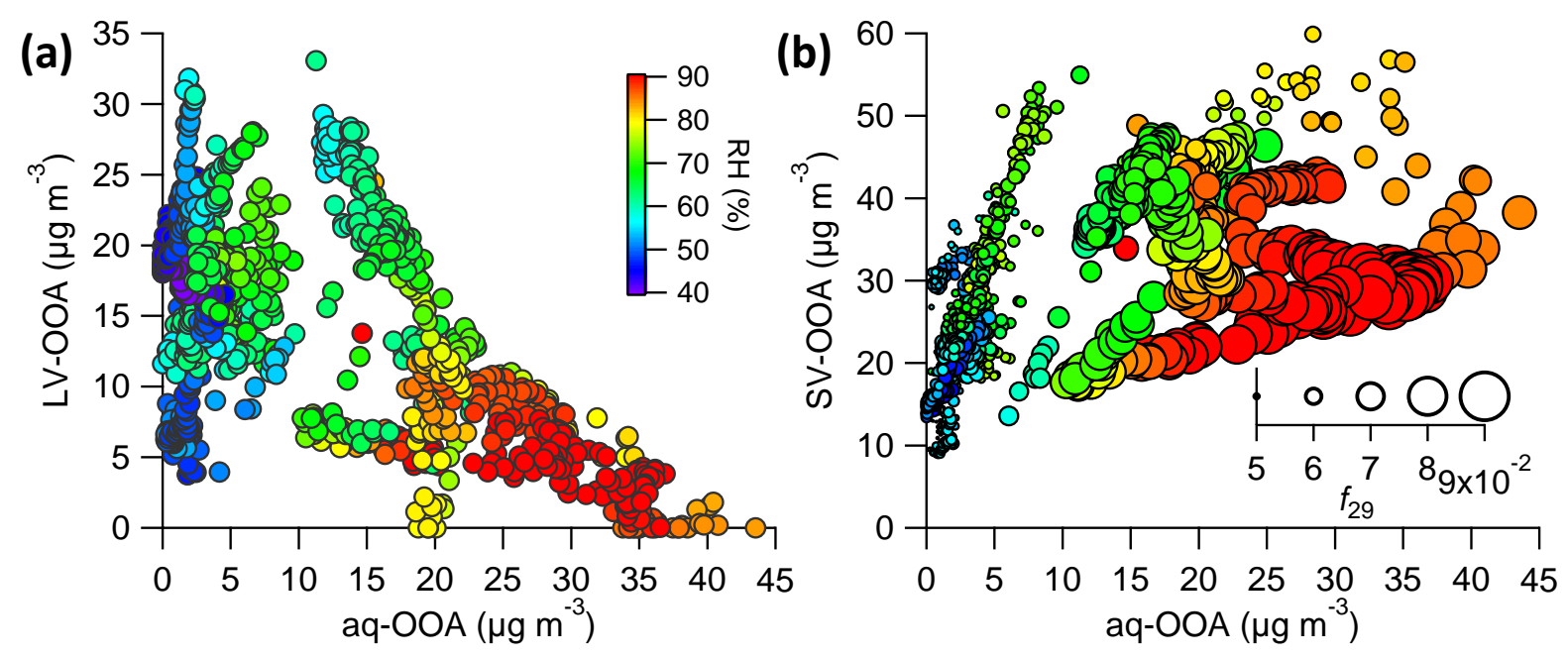

491

492

493

494

495

496

497

498

499

500

501

502

503

504

505

506

507

508

509

510

511

Figure 7. Scatter plots of (a) LV-OOA vs. aq-OOA and (b) SV-OOA vs. aq-OOA colored by RH during Ep1.

However, $\overline{\mathrm{OS}} c$ shows an increase trend when $\mathrm{RH}>70 \%$. One explanation is that highly oxygenated organic precursors with high polarity and water solubility tend to condense into the particle phase under high RH conditions (Ervens et al., 2011; Volkamer et al., 2007), and these aqueous phase-related SOA contributed to high oxidation state of OA. Another reason might be the potential formation of oxygen-containing functional groups through aqueous-phase reactions. As shown in Figure 6b, $f_{29}$ of OA showed a significant enhancement from 0.06 to 0.09 when $\mathrm{RH}$ increased from $60 \%$ to $90 \%$. Based on laboratory analysis of organic standards with different functional groups, Canagaratna et al. (2015) found that low $f_{\mathrm{CHO}+}(<0.05)$ was typically observed in mass spectra of organic compounds without alcohol functional group, while high $f_{\mathrm{CHO}+}(0.05-$ 0.12) was mainly associated with alcohol-compounds. Therefore high $f_{\mathrm{CHO}}$ under high $\mathrm{RH}$ conditions supports the potential formation of organic compounds with hydroxyl groups, which contributed to the increase of $\overline{\mathrm{OS}} c$ at high $\mathrm{RH}$ in this study. Figure $7 \mathrm{~b}$ further demonstrates that $f_{\mathrm{CHO}+}$ is highly correlated with formation of aq-OOA.

\section{Conclusions}

The sources and processes of OA during four haze episodes from 17 to 30 December in 2016 in urban Beijing were investigated. The average mass concentrations of OA ranged from 43.8 to $87.9 \mu \mathrm{g} \mathrm{m}^{-3}$ during haze episodes, with a dominant contribution of SOA to OA $(46-66 \%)$. FFOA was the most important contributor among POA factors contributing $13-31 \%$ to OA, 
indicating possible impacts of regional transport from the south and southwest of Beijing where raw coal was still used for residential heating. An aqueous phase-related factor, aq-OOA was identified which presented high concentrations (up to $40 \mu \mathrm{g} \mathrm{m}^{-3}$ ) during periods with high RH. The fact that aq-OOA tracked well with sulfate $\left(r^{2}=0.76\right)$ and AWC $\left(r^{2}=0.74\right)$ supported the presence of aqueous phase-related processes. Further analysis showed that 1) aq-OOA was located in the middle of $f_{44}$ vs. $f_{43}$ triangle plot, which can be used as a diagnostic for the presence of aqueous-phase processing of SOA; 2) slightly higher $f_{60}$ values of aq-OOA above the background level were observed than other SOA factors, revealing the potential participation of BBOA in aqueous-phase processing. The increases of $f_{29}$ (mainly $\mathrm{CHO}^{+}$) and $\mathrm{SO}_{2}{ }^{+} / \mathrm{SO}_{3}{ }^{+}$as a function of $\mathrm{RH}$, the triangle plot of $f_{\mathrm{H}_{2} \mathrm{SO}_{4}^{+}}$vs. $f_{\mathrm{HSO}_{3}^{+}}$during the most severe haze episode (Ep1), and high N/C ratio of aq-OOA and WSOA all demonstrate the potential formation of organic compounds enriched in nitrogen, sulfur and hydroxyl functional groups through aqueous-phase processing.

\section{Acknowledgments}

This work was supported by the National Natural Science Foundation of China (91744207, 41575120) and the National Key R\&D Program of China (2017YFC0212704, 2017YFC0209601). Jian Zhao thanks the support of the UCAS Joint PhD Training Program (NO. UCAS[2015]37). The data used are listed in references, tables (Tables S1-S4), figures, and supporting information.

\section{References}

Aiken, A. C., DeCarlo, P. F., and Jimenez, J. L.: Elemental analysis of organic species with electron ionization high-resolution mass spectrometry, Anal. chem., 79, 8350-8358, 2007.

Aiken, A. C., Decarlo, P. F., Kroll, J. H., Worsnop, D. R., Huffman, J. A., Docherty, K. S., Ulbrich, I. M., Mohr, C., Kimmel, J. R., and Sueper, D.: O/C and OM/OC ratios of primary, secondary, and ambient organic aerosols with high-resolution time-of-flight aerosol mass spectrometry, Environ. Sci. Technol., 42, 4478-4485, 2008.

Aiken, A. C., Salcedo, D., Cubison, M. J., Huffman, J. A., DeCarlo, P. F., Ulbrich, I. M., Docherty, K. S., Sueper, D., Kimmel, J. R., Worsnop, D. R., Trimborn, A., Northway, M., Stone, E. A., Schauer, J. J., Volkamer, R. M., Fortner, E., de Foy, B., Wang, J., Laskin, A., Shutthanandan, V., Zheng, J., Zhang, R., Gaffney, J., Marley, N. A., Paredes-Miranda, G., 
Arnott, W. P., Molina, L. T., Sosa, G., and Jimenez, J. L.: Mexico City aerosol analysis during MILAGRO using high resolution aerosol mass spectrometry at the urban supersite (T0) - Part 1: Fine particle composition and organic source apportionment, Atmos. Chem. Phys., 9, 6633-6653, 10.5194/acp-9-6633-2009, 2009.

Alfarra, M. R., Prevot, A. S., Szidat, S., Sandradewi, J., Weimer, S., Lanz, V. A., Schreiber, D., Mohr, M., and Baltensperger, U.: Identification of the mass spectral signature of organic aerosols from wood burning emissions, Environ. Sci. Technol., 41, 5770-5777, 2007.

Boucher, O., Randall, D., Artaxo, P., Bretherton, C., Feingold, G., Forster, P., Kerminen, V.-M., Kondo, Y., Liao, H., and Lohmann, U.: Clouds and aerosols, in: Climate change 2013: the physical science basis. Contribution of Working Group I to the Fifth Assessment Report of the Intergovernmental Panel on Climate Change, Cambridge University Press, 571-657, 2013.

Canagaratna, M., Jayne, J., Jimenez, J., Allan, J., Alfarra, M., Zhang, Q., Onasch, T., Drewnick, F., Coe, H., and Middlebrook, A.: Chemical and microphysical characterization of ambient aerosols with the aerodyne aerosol mass spectrometer, Mass Spectrom. Rev., 26, 185-222, 2007.

Canagaratna, M. R., Jimenez, J. L., Kroll, J. H., Chen, Q., Kessler, S. H., Massoli, P., Hildebrandt Ruiz, L., Fortner, E., Williams, L. R., Wilson, K. R., Surratt, J. D., Donahue, N. M., Jayne, J. T., and Worsnop, D. R.: Elemental ratio measurements of organic compounds using aerosol mass spectrometry: characterization, improved calibration, and implications, Atmos. Chem. Phys., 15, 253-272, 10.5194/acp-15-253-2015, 2015.

Chan, C. K., and Yao, X.: Air pollution in mega cities in China, Atmos. Environ., 42, 1-42, 2008. Chen, C., Sun, Y. L., Xu, W. Q., Du, W., Zhou, L. B., Han, T. T., Wang, Q. Q., Fu, P. Q., Wang, Z. F., Gao, Z. Q., Zhang, Q., and Worsnop, D. R.: Characteristics and sources of submicron aerosols above the urban canopy $(260 \mathrm{~m})$ in Beijing, China, during the 2014 APEC summit, Atmos. Chem. Phys., 15, 12879-12895, 10.5194/acp-15-12879-2015, 2015.

Chen, Y., Xu, L., Humphry, T., Hettiyadura, A. P. S., Ovadnevaite, J., Huang, S., Poulain, L., Schroder, J. C., Campuzano-Jost, P., Jimenez, J. L., Herrmann, H., O’Dowd, C., Stone, E. A., and Ng, N. L.: Response of the Aerodyne Aerosol Mass Spectrometer to Inorganic Sulfates and Organosulfur Compounds: Applications in Field and Laboratory Measurements, Environ. Sci. Technol., 53, 5176-5186, 10.1021/acs.est.9b00884, 2019.

Costa, J. F. P. d.: Weighted Correlation, in: International Encyclopedia of Statistical Science, edited by: Lovric, M., Springer Berlin Heidelberg, Berlin, Heidelberg, 1653-1655, 2011.

Cubison, M. J., Ortega, A. M., Hayes, P. L., Farmer, D. K., Day, D., Lechner, M. J., Brune, W. H., Apel, E., Diskin, G. S., Fisher, J. A., Fuelberg, H. E., Hecobian, A., Knapp, D. J., Mikoviny, T., Riemer, D., Sachse, G. W., Sessions, W., Weber, R. J., Weinheimer, A. J., Wisthaler, A., and Jimenez, J. L.: Effects of aging on organic aerosol from open biomass burning smoke in aircraft and laboratory studies, Atmos. Chem. Phys., 11, 12049-12064, 10.5194/acp-11-12049-2011, 2011.

DeCarlo, P. F., Kimmel, J. R., Trimborn, A., Northway, M. J., Jayne, J. T., Aiken, A. C., Gonin, M., Fuhrer, K., Horvath, T., and Docherty, K. S.: Field-deployable, high-resolution, time-offlight aerosol mass spectrometer, Anal. chem., 78, 8281-8289, 2006.

DeCarlo, P. F., Ulbrich, I. M., Crounse, J., de Foy, B., Dunlea, E. J., Aiken, A. C., Knapp, D., Weinheimer, A. J., Campos, T., Wennberg, P. O., and Jimenez, J. L.: Investigation of the sources and processing of organic aerosol over the Central Mexican Plateau from aircraft measurements during MILAGRO, Atmos. Chem. Phys., 10, 5257-5280, 10.5194/acp-10- 
5257-2010, 2010.

Donahue, N. M., Robinson, A. L., Stanier, C. O., and Pandis, S. N.: Coupled partitioning, dilution, and chemical aging of semivolatile organics, Environ. Sci. Technol., 40, 26352643, 10.1021/es052297c, 2006.

Draxler, R. R., and Hess, G.: An overview of the HYSPLIT_4 modelling system for trajectories, Australian meteorological magazine, 47, 295-308, 1998.

Dzepina, K., Arey, J., Marr, L. C., Worsnop, D. R., Salcedo, D., Zhang, Q., Onasch, T. B., Molina, L. T., Molina, M. J., and Jimenez, J. L.: Detection of particle-phase polycyclic aromatic hydrocarbons in Mexico City using an aerosol mass spectrometer, Int. J. Mass spectrom., 263, 152-170, 10.1016/j.ijms.2007.01.010, 2007.

Ebenstein, A., Fan, M., Greenstone, M., He, G., and Zhou, M.: New evidence on the impact of sustained exposure to air pollution on life expectancy from China's Huai River Policy, Proc. Natl. Acad. Sci. USA, 114, 10384-10389, 10.1073/pnas.1616784114, 2017.

Elser, M., Huang, R.-J., Wolf, R., Slowik, J. G., Wang, Q., Canonaco, F., Li, G., Bozzetti, C., Daellenbach, K. R., Huang, Y., Zhang, R., Li, Z., Cao, J., Baltensperger, U., El-Haddad, I., and Prévôt, A. S. H.: New insights into $\mathrm{PM}<\mathrm{sub}>2.5</$ sub $>$ chemical composition and sources in two major cities in China during extreme haze events using aerosol mass spectrometry, Atmos. Chem. Phys., 16, 3207-3225, 10.5194/acp-16-3207-2016, 2016.

Ervens, B., Turpin, B. J., and Weber, R. J.: Secondary organic aerosol formation in cloud droplets and aqueous particles (aqSOA): a review of laboratory, field and model studies, Atmos. Chem. Phys., 11, 11069-11102, 10.5194/acp-11-11069-2011, 2011.

Fountoukis, C., and Nenes, A.: ISORROPIA II: a computationally efficient thermodynamic equilibrium model for $\mathrm{K}+$; $\mathrm{Ca} 2+$; $\mathrm{Mg} 2+$; $\mathrm{NH} 4+$; $\mathrm{Na}+$; SO42-; NO3-; $\mathrm{Cl}-$; H2O aerosols, Atmos. Chem. Phys., 7, 4639-4659, 10.5194/acp-7-4639-2007, 2007.

Ge, X., Zhang, Q., Sun, Y., Ruehl, C. R., and Setyan, A.: Effect of aqueous-phase processing on aerosol chemistry and size distributions in Fresno, California, during wintertime, Environmental Chemistry, 9, 221-235, 10.1071/en11168, 2012.

Gilardoni, S., Massoli, P., Paglione, M., Giulianelli, L., Carbone, C., Rinaldi, M., Decesari, S., Sandrini, S., Costabile, F., Gobbi, G. P., Pietrogrande, M. C., Visentin, M., Scotto, F., Fuzzi, S., and Facchini, M. C.: Direct observation of aqueous secondary organic aerosol from biomass-burning emissions, Proc. Natl. Acad. Sci. USA, 113, 10013-10018, 10.1073/pnas.1602212113, 2016.

Han, S., Kondo, Y., Oshima, N., Takegawa, N., Miyazaki, Y., Hu, M., Lin, P., Deng, Z., Zhao, Y., Sugimoto, N., and $\mathrm{Wu}, \mathrm{Y}$.: Temporal variations of elemental carbon in Beijing, J. Geophys. Res., 114, D23202, 10.1029/2009jd012027, 2009.

He, L. Y., Lin, Y., Huang, X. F., Guo, S., Xue, L., Su, Q., Hu, M., Luan, S. J., and Zhang, Y. H.: Characterization of high-resolution aerosol mass spectra of primary organic aerosol emissions from Chinese cooking and biomass burning, Atmos. Chem. Phys., 10, 1153511543, 10.5194/acp-10-11535-2010, 2010.

Heald, C. L., Kroll, J. H., Jimenez, J. L., Docherty, K. S., DeCarlo, P. F., Aiken, A. C., Chen, Q., Martin, S. T., Farmer, D. K., and Artaxo, P.: A simplified description of the evolution of organic aerosol composition in the atmosphere, Geophys. Res. Lett., 37, L08803, 10.1029/2010g1042737, 2010.

Hildebrandt, L., Engelhart, G. J., Mohr, C., Kostenidou, E., Lanz, V. A., Bougiatioti, A., DeCarlo, P. F., Prevot, A. S. H., Baltensperger, U., Mihalopoulos, N., Donahue, N. M., and Pandis, S. N.: Aged organic aerosol in the Eastern Mediterranean: the Finokalia Aerosol 
Measurement Experiment - 2008, Atmos. Chem. Phys., 10, 4167-4186, 10.5194/acp-104167-2010, 2010.

Hu, W., Hu, M., Hu, W., Jimenez, J. L., Yuan, B., Chen, W., Wang, M., Wu, Y., Chen, C., and Wang, Z.: Chemical composition, sources, and aging process of submicron aerosols in Beijing: Contrast between summer and winter, J. Geophys. Res.-Atmos., 121, 1955-1977, 10.1002/2015JD024020, 2016.

Huang, R.-J., Zhang, Y., Bozzetti, C., Ho, K.-F., Cao, J.-J., Han, Y., Daellenbach, K. R., Slowik, J. G., Platt, S. M., Canonaco, F., Zotter, P., Wolf, R., Pieber, S. M., Bruns, E. A., Crippa, M., Ciarelli, G., Piazzalunga, A., Schwikowski, M., Abbaszade, G., Schnelle-Kreis, J., Zimmermann, R., An, Z., Szidat, S., Baltensperger, U., Haddad, I. E., and Prévôt, A. S. H.: High secondary aerosol contribution to particulate pollution during haze events in China, Nature, 514, 218-222, 10.1038/nature13774, 2014.

Huang, X. F., He, L. Y., Hu, M., Canagaratna, M. R., Sun, Y., Zhang, Q., Zhu, T., Xue, L., Zeng, L. W., Liu, X. G., Zhang, Y. H., Jayne, J. T., Ng, N. L., and Worsnop, D. R.: Highly timeresolved chemical characterization of atmospheric submicron particles during 2008 Beijing Olympic Games using an Aerodyne High-Resolution Aerosol Mass Spectrometer, Atmos. Chem. Phys., 10, 8933-8945, 10.5194/acp-10-8933-2010, 2010.

Jayne, J. T., Leard, D. C., Zhang, X., Davidovits, P., Smith, K. A., Kolb, C. E., and Worsnop, D. R.: Development of an Aerosol Mass Spectrometer for Size and Composition Analysis of Submicron Particles, Aerosol Sci. Technol., 33, 49-70, 10.1080/027868200410840, 2000.

Jimenez, J., Canagaratna, M., Donahue, N., Prevot, A., Zhang, Q., Kroll, J. H., DeCarlo, P. F., Allan, J. D., Coe, H., and Ng, N.: Evolution of organic aerosols in the atmosphere, Science, 326, 1525-1529, 2009.

Kaltsonoudis, C., Kostenidou, E., Louvaris, E., Psichoudaki, M., Tsiligiannis, E., Florou, K., Liangou, A., and Pandis, S. N.: Characterization of fresh and aged organic aerosol emissions from meat charbroiling, Atmos. Chem. Phys., 17, 7143-7155, 10.5194/acp-177143-2017, 2017.

Kim, H., Collier, S., Ge, X., Xu, J., Sun, Y., Jiang, W., Wang, Y., Herckes, P., and Zhang, Q.: Chemical processing of water-soluble species and formation of secondary organic aerosol in fogs, Atmos. Environ., 200, 158-166, https://doi.org/10.1016/j.atmosenv.2018.11.062, 2019.

Kroll, J. H., Donahue, N. M., Jimenez, J. L., Kessler, S. H., Canagaratna, M. R., Wilson, K. R., Altieri, K. E., Mazzoleni, L. R., Wozniak, A. S., and Bluhm, H.: Carbon oxidation state as a metric for describing the chemistry of atmospheric organic aerosol, Nat. Chem., 3, 133-139, 2011.

Lanz, V., Alfarra, M., Baltensperger, U., Buchmann, B., Hueglin, C., and Prévôt, A.: Source apportionment of submicron organic aerosols at an urban site by factor analytical modelling of aerosol mass spectra, Atmos. Chem. Phys., 7, 1503-1522, 2007.

Li, L., Ren, L., Ren, H., Yue, S., Xie, Q., Zhao, W., Kang, M., Li, J., Wang, Z., Sun, Y., and Fu, P.: Molecular Characterization and Seasonal Variation in Primary and Secondary Organic Aerosols in Beijing, China, J. Geophys. Res.- Atmos., 123, 12394-12412, doi:10.1029/2018JD028527, 2018.

Li, Y. J., Sun, Y., Zhang, Q., Li, X., Li, M., Zhou, Z., and Chan, C. K.: Real-time chemical characterization of atmospheric particulate matter in China: A review, Atmos. Environ., 158, 270-304, 10.1016/j.atmosenv.2017.02.027, 2017.

Lim, Y. B., Tan, Y., Perri, M. J., Seitzinger, S. P., and Turpin, B. J.: Aqueous chemistry and its role in secondary organic aerosol (SOA) formation, Atmos. Chem. Phys., 10, 10521-10539, 
10.5194/acp-10-10521-2010, 2010.

Liu, Q., Sun, Y., Hu, B., Liu, Z., Akio, S., and Wang, Y.: In situ measurement of PM1 organic aerosol in Beijing winter using a high-resolution aerosol mass spectrometer, Chin. Sci. Bull., 57, 819-826, 10.1007/s11434-011-4886-0, 2012.

Matthew, B. M., Middlebrook, A. M., and Onasch, T. B.: Collection Efficiencies in an Aerodyne Aerosol Mass Spectrometer as a Function of Particle Phase for Laboratory Generated Aerosols, Aerosol Sci. Technol., 42, 884-898, 10.1080/02786820802356797, 2008.

Middlebrook, A. M., Bahreini, R., Jimenez, J. L., and Canagaratna, M. R.: Evaluation of Composition-Dependent Collection Efficiencies for the Aerodyne Aerosol Mass Spectrometer using Field Data, Aerosol Sci. Technol., 46, 258-271, 10.1080/02786826.2011.620041, 2012.

Mohr, C., DeCarlo, P. F., Heringa, M. F., Chirico, R., Slowik, J. G., Richter, R., Reche, C., Alastuey, A., Querol, X., Seco, R., Peñuelas, J., Jiménez, J. L., Crippa, M., Zimmermann, R., Baltensperger, U., and Prévôt, A. S. H.: Identification and quantification of organic aerosol from cooking and other sources in Barcelona using aerosol mass spectrometer data, Atmos. Chem. Phys., 12, 1649-1665, 10.5194/acp-12-1649-2012, 2012.

Nenes, A., Pandis, S. N., and Pilinis, C.: ISORROPIA: A new thermodynamic equilibrium model for multiphase multicomponent inorganic aerosols, Aquatic geochemistry, 4, 123-152, 1998.

Ng, N., Canagaratna, M., Jimenez, J., Zhang, Q., Ulbrich, I., and Worsnop, D.: Real-time methods for estimating organic component mass concentrations from aerosol mass spectrometer data, Environ. Sci. Technol., 45, 910-916, $2011 \mathrm{a}$.

Ng, N. L., Canagaratna, M. R., Zhang, Q., Jimenez, J. L., Tian, J., Ulbrich, I. M., Kroll, J. H., Docherty, K. S., Chhabra, P. S., Bahreini, R., Murphy, S. M., Seinfeld, J. H., Hildebrandt, L., Donahue, N. M., DeCarlo, P. F., Lanz, V. A., Prévôt, A. S. H., Dinar, E., Rudich, Y., and Worsnop, D. R.: Organic aerosol components observed in Northern Hemispheric datasets from Aerosol Mass Spectrometry, Atmos. Chem. Phys., 10, 4625-4641, 10.5194/acp-104625-2010, 2010.

Ng, N. L., Canagaratna, M. R., Jimenez, J. L., Chhabra, P. S., Seinfeld, J. H., and Worsnop, D. R.: Changes in organic aerosol composition with aging inferred from aerosol mass spectra, Atmos. Chem. Phys., 11, 6465-6474, 10.5194/acp-11-6465-2011, $2011 \mathrm{~b}$.

Odum, J. R., Hoffmann, T., Bowman, F., Collins, D., Flagan, R. C., and Seinfeld, J. H.: Gas/particle partitioning and secondary organic aerosol yields, Environ. Sci. Technol., 30, 2580-2585, 1996.

Paatero, P., and Tapper, U.: Positive matrix factorization: A non - negative factor model with optimal utilization of error estimates of data values, Environmetrics, 5, 111-126, 1994.

Qiu, Y., Xie, Q., Wang, J., Xu, W., Li, L., Wang, Q., Zhao, J., Chen, Y., Chen, Y., Wu, Y., Du, W., Zhou, W., Lee, J. D., Zhao, C., Ge, X., Fu, P., Wang, Z., Worsnop, D. R., and Sun, Y.: Vertical Characterization and Source Apportionment of Water-soluble Organic Aerosol with High-resolution Aerosol Mass Spectrometry in Beijing, China, ACS Earth and Space Chemistry, 3, 273-284, 10.1021/acsearthspacechem.8b00155, 2019.

Quan, J. N., Tie, X. X., Zhang, Q., Liu, Q., Li, X., Gao, Y., and Zhao, D. L.: Characteristics of heavy aerosol pollution during the 2012-2013 winter in Beijing, China, Atmos. Environ., 88, 83-89, 10.1016/j.atmosenv.2014.01.058, 2014.

Setyan, A., Flament, P., Locoge, N., Deboudt, K., Riffault, V., Alleman, L. Y., Schoemaecker, C., Arndt, J., Augustin, P., Healy, R. M., Wenger, J. C., Cazier, F., Delbarre, H., Dewaele, D., Dewalle, P., Fourmentin, M., Genevray, P., Gengembre, C., Leonardis, T., Marris, H., and 
Mbengue, S.: Investigation on the near-field evolution of industrial plumes from metalworking activities, Sci. Total Environ., 668, 443-456, https://doi.org/10.1016/j.scitotenv.2019.02.399, 2019.

Song, S., Gao, M., Xu, W., Sun, Y., Worsnop, D. R., Jayne, J. T., Zhang, Y., Zhu, L., Li, M., Zhou, Z., Cheng, C., Lv, Y., Wang, Y., Peng, W., Xu, X., Lin, N., Wang, Y., Wang, S., Munger, J. W., Jacob, D. J., and McElroy, M. B.: Possible heterogeneous chemistry of hydroxymethanesulfonate (HMS) in northern China winter haze, Atmos. Chem. Phys., 19, 1357-1371, 10.5194/acp-19-1357-2019, 2019.

Stein, A. F., Draxler, R. R., Rolph, G. D., Stunder, B. J. B., Cohen, M. D., and Ngan, F.: NOAA's HYSPLIT Atmospheric Transport and Dispersion Modeling System, Bulletin of the American Meteorological Society, 96, 2059-2077, 10.1175/bams-d-14-00110.1, 2015.

Sun, Y., Zhang, Q., Zheng, M., Ding, X., Edgerton, E. S., and Wang, X.: Characterization and source apportionment of water-soluble organic matter in atmospheric fine particles (PM2.5) with high-resolution aerosol mass spectrometry and GC-MS, Environ. Sci. Technol., 45, 4854-4861, 10.1021/es200162h, 2011a.

Sun, Y., Wang, Z., Fu, P., Jiang, Q., Yang, T., Li, J., and Ge, X.: The impact of relative humidity on aerosol composition and evolution processes during wintertime in Beijing, China, Atmos. Environ., 77, 927-934, 10.1016/j.atmosenv.2013.06.019, 2013a.

Sun, Y., Jiang, Q., Wang, Z., Fu, P., Li, J., Yang, T., and Yin, Y.: Investigation of the sources and evolution processes of severe haze pollution in Beijing in January 2013, J. Geophys. Res.Atmos., 119, 4380-4398, 10.1002/2014jd021641, 2014.

Sun, Y., Chen, C., Zhang, Y., Xu, W., Zhou, L., Cheng, X., Zheng, H., Ji, D., Li, J., Tang, X., Fu, P., and Wang, Z.: Rapid formation and evolution of an extreme haze episode in Northern China during winter 2015, Sci. Rep., 6, 27151, 10.1038/srep27151, 2016a.

Sun, Y., Du, W., Fu, P., Wang, Q., Li, J., Ge, X., Zhang, Q., Zhu, C., Ren, L., Xu, W., Zhao, J., Han, T., Worsnop, D. R., and Wang, Z.: Primary and secondary aerosols in Beijing in winter: sources, variations and processes, Atmos. Chem. Phys., 16, 8309-8329, 10.5194/acp-16-8309-2016, 2016 b.

Sun, Y., Xu, W., Zhang, Q., Jiang, Q., Canonaco, F., Prévôt, A. S. H., Fu, P., Li, J., Jayne, J., Worsnop, D. R., and Wang, Z.: Source apportionment of organic aerosol from 2-year highly time-resolved measurements by an aerosol chemical speciation monitor in Beijing, China, Atmos. Chem. Phys., 18, 8469-8489, 10.5194/acp-18-8469-2018, 2018.

Sun, Y. L., Zhang, Q., Schwab, J. J., Demerjian, K. L., Chen, W. N., Bae, M. S., Hung, H. M., Hogrefe, O., Frank, B., Rattigan, O. V., and Lin, Y. C.: Characterization of the sources and processes of organic and inorganic aerosols in New York city with a high-resolution timeof-flight aerosol mass apectrometer, Atmos. Chem. Phys., 11, 1581-1602, 10.5194/acp-111581-2011, 2011b.

Sun, Y. L., Wang, Z. F., Fu, P. Q., Yang, T., Jiang, Q., Dong, H. B., Li, J., and Jia, J. J.: Aerosol composition, sources and processes during wintertime in Beijing, China, Atmos. Chem. Phys., 13, 4577-4592, 10.5194/acp-13-4577-2013, 2013 b.

Sun, Y. L., Wang, Z. F., Du, W., Zhang, Q., Wang, Q. Q., Fu, P. Q., Pan, X. L., Li, J., Jayne, J., and Worsnop, D. R.: Long-term real-time measurements of aerosol particle composition in Beijing, China: seasonal variations, meteorological effects, and source analysis, Atmos. Chem. Phys., 15, 10149-10165, 10.5194/acp-15-10149-2015, 2015.

Ulbrich, I., Canagaratna, M., Zhang, Q., Worsnop, D., and Jimenez, J.: Interpretation of organic components from Positive Matrix Factorization of aerosol mass spectrometric data, Atmos. 
Chem. Phys., 9, 2891-2918, 2009.

Volkamer, R., San Martini, F., Molina, L. T., Salcedo, D., Jimenez, J. L., and Molina, M. J.: A missing sink for gas-phase glyoxal in Mexico City: Formation of secondary organic aerosol, Geophys. Res. Lett., 34, L19807, 10.1029/2007g1030752, 2007.

Wang, G., Zhang, R., Gomez, M. E., Yang, L., Levy Zamora, M., Hu, M., Lin, Y., Peng, J., Guo, S., Meng, J., Li, J., Cheng, C., Hu, T., Ren, Y., Wang, Y., Gao, J., Cao, J., An, Z., Zhou, W., Li, G., Wang, J., Tian, P., Marrero-Ortiz, W., Secrest, J., Du, Z., Zheng, J., Shang, D., Zeng, L., Shao, M., Wang, W., Huang, Y., Wang, Y., Zhu, Y., Li, Y., Hu, J., Pan, B., Cai, L., Cheng, Y., Ji, Y., Zhang, F., Rosenfeld, D., Liss, P. S., Duce, R. A., Kolb, C. E., and Molina, M. J.: Persistent sulfate formation from London Fog to Chinese haze, Proc. Natl. Acad. Sci. USA, 113, 13630-13635, 10.1073/pnas.1616540113, 2016.

Wang, Q., Sun, Y., Jiang, Q., Du, W., Sun, C., Fu, P., and Wang, Z.: Chemical composition of aerosol particles and light extinction apportionment before and during the heating season in Beijing, China, J. Geophys. Res.-Atmos., 120, 12708-12722, 10.1002/2015jd023871, 2015.

Wang, Y., Zhang, Q., Jiang, J., Zhou, W., Wang, B., He, K., Duan, F., Zhang, Q., Philip, S., and Xie, Y.: Enhanced sulfate formation during China's severe winter haze episode in January 2013 missing from current models, J. Geophys. Res.- Atmos., 119, 10,425-410,440, 10.1002/2013jd021426, 2014.

Xu, L., Guo, H., Weber, R. J., and Ng, N. L.: Chemical Characterization of Water-Soluble Organic Aerosol in Contrasting Rural and Urban Environments in the Southeastern United States, Environ. Sci. Technol., 51, 78-88, 10.1021/acs.est.6b05002, 2017a.

Xu, W., Han, T., Du, W., Wang, Q., Chen, C., Zhao, J., Zhang, Y., Li, J., Fu, P., Wang, Z., Worsnop, D. R., and Sun, Y.: Effects of Aqueous-Phase and Photochemical Processing on Secondary Organic Aerosol Formation and Evolution in Beijing, China, Environ. Sci. Technol., 51, 762-770, 10.1021/acs.est.6b04498, $2017 \mathrm{~b}$.

Xu, W., Sun, Y., Wang, Q., Du, W., Zhao, J., Ge, X., Han, T., Zhang, Y., Zhou, W., Li, J., Fu, P., Wang, Z., and Worsnop, D. R.: Seasonal Characterization of Organic Nitrogen in Atmospheric Aerosols Using High Resolution Aerosol Mass Spectrometry in Beijing, China, ACS Earth and Space Chemistry, 1, 673-682, 10.1021/acsearthspacechem.7b00106, $2017 \mathrm{c}$.

Xu, W., Sun, Y., Wang, Q., Zhao, J., Wang, J., Ge, X., Xie, C., Zhou, W., Du, W., Li, J., Fu, P., Wang, Z., Worsnop, D. R., and Coe, H.: Changes in Aerosol Chemistry From 2014 to 2016 in Winter in Beijing: Insights From High-Resolution Aerosol Mass Spectrometry, J. Geophys. Res.- Atmos., 124, 1132-1147, 10.1029/2018jd029245, 2019.

Xu, W. Q., Sun, Y. L., Chen, C., Du, W., Han, T. T., Wang, Q. Q., Fu, P. Q., Wang, Z. F., Zhao, X. J., Zhou, L. B., Ji, D. S., Wang, P. C., and Worsnop, D. R.: Aerosol composition, oxidation properties, and sources in Beijing: results from the 2014 Asia-Pacific Economic Cooperation summit study, Atmos. Chem. Phys., 15, 13681-13698, 10.5194/acp-15-136812015, 2015.

Zhang, J. K., Sun, Y., Liu, Z. R., Ji, D. S., Hu, B., Liu, Q., and Wang, Y. S.: Characterization of submicron aerosols during a month of serious pollution in Beijing, 2013, Atmos. Chem. Phys., 14, 2887-2903, 10.5194/acp-14-2887-2014, 2014.

Zhang, J. K., Ji, D. S., Liu, Z. R., Hu, B., Wang, L. L., Huang, X. J., and Wang, Y. S.: New characteristics of submicron aerosols and factor analysis of combined organic and inorganic aerosol mass spectra during winter in Beijing, Atmos. Chem. Phys. Discuss., 2015, 1853718576, 10.5194/acpd-15-18537-2015, 2015. 
Zhang, Q., Jimenez, J. L., Canagaratna, M. R., Ulbrich, I. M., Ng, N. L., Worsnop, D. R., and Sun, Y.: Understanding atmospheric organic aerosols via factor analysis of aerosol mass spectrometry: a review, Anal Bioanal Chem, 401, 3045-3067, 10.1007/s00216-011-5355-y, 2011.

Zhang, Q. H., Zhang, J. P., and Xue, H. W.: The challenge of improving visibility in Beijing, Atmos. Chem. Phys., 10, 7821-7827, 10.5194/acp-10-7821-2010, 2010.

Zhang, Y., Sun, Y., Du, W., Wang, Q., Chen, C., Han, T., Lin, J., Zhao, J., Xu, W., Gao, J., Li, J., $\mathrm{Fu}$, P., Wang, Z., and Han, Y.: Response of aerosol composition to different emission scenarios in Beijing, China, Sci. Total Environ., 571, 902-908, 10.1016/j.scitotenv.2016.07.073, 2016.

Zhang, Y., Wang, Y., Zhang, X., Shen, X., Sun, J., Wu, L., Zhang, Z., and Che, H.: Chemical Components, Variation, and Source Identification of PM1 during the Heavy Air Pollution Episodes in Beijing in December 2016, Journal of Meteorological Research, 32, 1-13, 10.1007/s13351-018-7051-8, 2018.

Zhao, J., Du, W., Zhang, Y., Wang, Q., Chen, C., Xu, W., Han, T., Wang, Y., Fu, P., Wang, Z., Li, Z., and Sun, Y.: Insights into aerosol chemistry during the 2015 China Victory Day parade: results from simultaneous measurements at ground level and $260 \mathrm{~m}$ in Beijing, Atmos. Chem. Phys., 17, 3215-3232, 10.5194/acp-17-3215-2017, 2017.

Zheng, B., Zhang, Q., Zhang, Y., He, K. B., Wang, K., Zheng, G. J., Duan, F. K., Ma, Y. L., and Kimoto, T.: Heterogeneous chemistry: a mechanism missing in current models to explain secondary inorganic aerosol formation during the January 2013 haze episode in North China, Atmos. Chem. Phys., 15, 2031-2049, 10.5194/acp-15-2031-2015, 2015a.

Zheng, G. J., Duan, F. K., Su, H., Ma, Y. L., Cheng, Y., Zheng, B., Zhang, Q., Huang, T., Kimoto, T., Chang, D., Pöschl, U., Cheng, Y. F., and He, K. B.: Exploring the severe winter haze in Beijing: the impact of synoptic weather, regional transport and heterogeneous reactions, Atmos. Chem. Phys., 15, 2969-2983, 10.5194/acp-15-2969-2015, $2015 \mathrm{~b}$.

Zhong, J., Zhang, X., Dong, Y., Wang, Y., Liu, C., Wang, J., Zhang, Y., and Che, H.: Feedback effects of boundary-layer meteorological factors on cumulative explosive growth of PM2.5 during winter heavy pollution episodes in Beijing from 2013 to 2016, Atmos. Chem. Phys., 18, 247-258, 10.5194/acp-18-247-2018, 2018. 